\title{
Göç, Göçebe, Göçer, Göçer evli/evlü, Göçer oba, Göçgün(cü)/Göçkün(cü), Göçmen/Göçmel ve Konargöçer/Göçerkonar Sözcükleri Üzerine Bazı Notlar ${ }^{1}$
}

\author{
Serdar BULUT \\ Doç. Dr., Alanya Alaaddin Keykubat Üniversitesi, \\ Eğitim Fakültesi, Temel Eğitim Bölümü \\ serdar.bulut@alanya.edu.tr \\ Orcid ID: https://orcid.org/0000-0001-6286-4873
}

\begin{abstract}
Öz
Göç olgusu özellikle ilk Türklerden beri var olan hatta destanlara konu olmuş bir olgudur. Göç insanın farklı coğrafyalar arasında bireysel yer değiştirme hareketi olarak görülebileceği gibi, özellikle savaş, kuraklık veya başka doğa olaylarının baskın olması durumlarında kitlesel düzeyde de gerçekleşebilmektedir. Asya bozkırlarından günümüz Yörük/Türkmen gruplarına gelinceye kadar Türk kültür tarihi incelendiği zaman Türklerin yaylak ve kışlaklar arasında belli döngülerle hareket halinde oldukları görülür. $\mathrm{Bu}$ hareket halindeyken hem hayvancılıkla uğraşmışlar hem de tarım yapmışlardır. $\mathrm{Bu}$ hareket çeşitli adlarla karşılanmış ama özellikle Yörük/Türkmen gruplar kendilerini konargöçer, göçerkonar, göçer gibi terimlerle ifade ederken konuya kavramsal açıdan yaklaşan araştırmacılar Türk tipi göç faaliyetlerini özellikle göçebe terimiyle karşılamaya çalışmışlardır. $\mathrm{Bu}$ terimler acaba Türk tipi göç faaliyetlerini karşılamada yeterli terimler midir? Konuyla ilgili Türkçe Sözlük, Derleme Sözlüğü ve Tarama Sözlüğü ile Eski Türkçe, Orta Türkçe ve Anadolu Türkçesi dönemi çalışmaları incelendiği zaman, "göçer, göçer evli/evlü, göçer oba, göçgün, göçkün, göçgüncü, göçküncü, göçmel” terimleri ile özellikle bir ülkeden başka bir ülkeye yerleşenleri karşılayan "göçmen" sözcüğü de karşımıza çıkar.

Uygur dönemi metinlerinde özellikle Köktürk harfli Taryat (Terhin) yazıtında ilk olarak "konar göçerim" şeklinde geçen sözcügü̈n zamanla farklı şekilleri nasıl oluşmuştur, bunlara dil kuralları içinde bakmak lazım. Çalışmamızda göç merkezli oluşan sözcüklerin tarihsel süreçlerine, etimolojik kökenlerine, kavramsal ve anlamsal boyutlarına bakılacak ve Türk kültür tarihi içinde tüm sözcüklerin benzerlik ve farklılık gösteren kısımlarına değinilecektir.
\end{abstract}

\footnotetext{
${ }^{1}$ Makale Geliş/Kabul Tarihi: 10.12.2021 / 28.12.2021

Künye Bilgisi: Bulut, S. (2021). Göç, Göçebe, göçer, göçer evli/evlü, göçer oba, göçgün(cü)/göçkün(cü), göçmen/göçmel ve konargöçer/göçerkonar sözcükleri üzerine bazı notlar. Kahramanmaraş Sütçü İmam Üniversitesi Sosyal Bilimler Dergisi, 18 (3), 1671-1720. DOI: 10.33437/ksusbd.1035352
} 
Anahtar Kelimeler: Göç, Konargöçer, Göçebe, Göçer evli, Yörük/Türkmen.

\title{
Some Notes on the Words Göç, Göçebe, Göçer, Göçer evli/evlü, Göçer oba, Göçgün(cü)/Göçkün(cü), Göçmen/Göçmel and Konargöçer/Göçerkonar
}

\begin{abstract}
The phenomenon of migration is a case that has existed since the first Turks in particular and has even been the subject of epics. While migration can be considered as an individual movement of people among different geographies, it can also occur at a mass level, notably in cases of war, drought or other natural events. When the history of Turkish culture is examined from the Asian steppes to today's Yoruk-Turkmen groups, it is understood that the Turks bristle between the highland and winter quarters at certain intervals. While they were on the move, they contend both livestock and agriculture. This movement was entitled with various names, but while Yoruk/Turkmen groups express themselves with terms such as "konargöçer" "göçerkonar" and "göçer", researchers who approach the subject conceptually tried to designate Turkish type migration activities with the term "nomad". Are these terms efficacious for meeting Turkish-type migration activities? When the related Turkish Dictionary, Compilation Dictionary and Scanning Dictionary and Old Turkish, Middle Turkish and Anatolian Turkish period studies are examined, the terms "göçer, göçer evli/evlü, göçer oba, göçgün, göçkün, göçgüncü, göçküncü, göçmel" are specially used besides "göçmen" which means those who settle in another country.

In the texts of the Uyghur period, mainly in the Köktürk letter Taryat (Terhin) inscription, it is essential to look at how the various forms of the word, which was first used as "konar göçerim", were formed over time, within the rules of language. In our study, the historical processes, etymological origins, conceptual and semantic dimensions of migration-centred words will be probed into and the similar and divergent places of all words in Turkish cultural history will be mentioned..
\end{abstract}

Keywords: Migration, Nomadic, Nomadic, Nomadic, Yoruk/Turkmen.

\section{Giriş}

İlk çağlardan günümüze bakıldığı zaman insanların hayvancılıkla geçindiği, çobanlık yaptığı ve yaşadıkları yerlerden farklı coğrafyalara göç ettikleri görülür. Bu göçler sürekli ve kalıcı göçler şeklinde olabildiği gibi özellikle bozkır kültürü içinde yaylaklar ve kışlaklar arasında gerçekleşen göçler şeklinde 
de görülebilmektedir. Özellikle Hunlar ve Göktürkler zamanında Türklerin hayvancılıkla geçimlerini sürdürdükleri ve hayvanların yeşil otlak alanlar bulması adına farklı coğrafyalara göçtükleri görülür.

Bozkır kültüründe yaşayan eski Türklerin en büyük geçim kaynakları besledikleri hayvanlardır. Aslında o dönem Türk ekonomisinin bozkır kültürünün de etkisi ile hayvancılık üzerine kurulu olduğu ifade edilebilir. Bu nedenle geçim ekonomisi Türklerin yerleşim yerlerini belirlemelerinde de etkili olmuştur. "Başlangıçta büyük hayvan kitlelerine sahip olan Türkler, 'Çadır-köy' veya 'Çadır-şehir' halinde, otları bol ve karı az olan, güneş gören bir yeri seçer ve oraya konarlardı." (Ögel, 2000: 9). "Kağanlar ile devletin ileri gelenlerinin sürüleri, genel olarak başkentlere veyahut da büyük şehirlere yakın olan yaylalarda otlardı." (Ögel, 2000: 11).

“Orta Asya'da konargöçer bir hayat yaşayan Türk toplulukları, kurdukları, yerleşim merkezleri çevresinde bu hayat tarzını devam ettirmişler ve zamanla yerleşik hayata geçmişlerdir. 11. yüzyılın sonlarından itibaren Anadolu'ya gelmeye ve yerleşmeye başlayan Türklerin bir bölümü anavatanları olan kurak Orta Asya steplerine uyumun gereği olan hayat tarzlarını Anadolu'da da sürdürmüşlerdir. Türklerin yerleşik hayata geçtiği ve yerleşik kültürlerin ağır bastığ 1 Selçuklu ve Osmanlı Devleti dönemlerinde de Türkmen ve Yörük adı altında toplanan büyük bir Türk kitlesi bu hayat tarzını devam ettirmiştir" (Kutlu, 1987: 3). Kutlu (1987)'nun burada Orta Asya olarak bahsettiği Türkistan coğrafyası Türk tipi göç faaliyetleri için önemli bir merkez olsa da Yörük/Türkmen grup tarafından Anadolu sahasında Türk tipi göç faaliyetleri önemli bir hayat tarzı olarak hâlâ sürdürülmektedir.

Eski Yunan filozofu Eflatun'un göçebeleri "vahşi aile grupları" olarak tanımlaması ve göçebe çobanların ilkel kitleler olduğu; "medeniyet"e ancak tarım hayatı ile geçildiği yönündeki iddiasını (Kafesoğlu, 2005: 33; Şenel, 1968: 206; Güvenç, 1971: 9-19; Büyükcan Say1lır, 2012: 565), 21. yüzy1lda da devam ettirmek büyük bir ikilemdir. Avcı toplayıcıları, hayvancı topluluklarla bir görüp onları "göçebe"likte birleştirmek tarihsel gelişmelere de aykırıdır. Avcı-toplayıcılar da göçebe bir topluluktur. Ancak onlar üretmeyen ve kendi ihtiyaçlarını karşılamak için göç eden gruplardır. Hâlbuki hayvancı göçerler kendileri için değil, hayvanlarının ihtiyaçları için göç ederler. Hayvancı göçerlerin hayatları, hayvanlarının doğal ihtiyacına bağlı olarak şekillenmiştir. Tarih boyunca otlaklar ve hayvanlar, göçün şeklini ve güzergâhını da belirlemiştir. Örneğin sığır ve koyun için gerekli olan otlar, deve ve keçi için gerekli ağaçlardan daha hızlı büyürler. İnekler her yerde koyunlardan daha fazla ota muhtaçtırlar. Develer ise seyrek bitki ortamında yaşayabilirler. Bu durum belirli hayvan cinsini seçmeyi zorunlu k1lar. Göçebeler kendi emeklerinin bulunmadığı geniş otlaklarda hayvanlarını besleyerek geçimlerini 
sağladıklarından hayat standartları tamamıyla tabiat şartlarına bağlıdır (Spooner, 1972: 122-124; Saydam, 2009: 28). Doğal olarak göç faaliyetlerini hayvanlar ve meralar odaklı bir şekilde organize etmişlerdir. Lakin Türk tipi göç faaliyetlerinde meraların ücretleri vardır ve ücretler vergi olarak tahsil edilir.

Türkler için düşünüldüğü zaman göç kavramı, yukarıda ayrıntılı şekilde bahsedildiği gibi genel olarak yaylacılık faaliyeti şeklinde hayvanlar daha iyi meralar bulsun diye yapılmıştır. Bunun temel sebebi yaşanılan bozkır kültürünün gerekliliği olarak kışları tarım yapılsa da özellikle hayvancılıkla geçim faaliyetlerinin yürütülmesi olmuştur. En eski Türk topluluklarından günümüz Anadolu ve Türkistan Yörük/Türkmen gruplarına gelinceye kadar bu kültür varlığını devam ettirmiştir. Günümüzde özellikle Anadolu'nun farklı bölgelerinde geçimlerini hayvancılıkla sağlayan, yazları serin yaylalarda çadırlarda yaşayan, kışları ise daha yerleşik oldukları sıcak yerlerdeki evlerine göç eden Yörük/Türkmen grubun konargöçer ve göçer kavramlarını daha çok tercih ettikleri görülmektedir.

Çalışmanın daha iyi anlaşılabilmesi ve somutlaştırılabilmesi için göç merkezli sözcükler tek tek ele alınarak değerlendirmeye çalışılacaktır.

\section{Köç (Göç) / Köç- (Göç-)}

Göç kavramına genel olarak bakıldığı zaman; göç: hareketli canlının geçici ya da sürekli olarak yaşam alanını değiştirmesi olayıdır. İnsanlarda olduğu gibi hayvanlarda da göç olayı vardır. Göç bir yerde canlının yaşamını ve soyunu sürdürme çabasının ürünüdür. Tarihin en eski döneminden beri insanlar gibi başka hareketli canlıların da geleceklerini tehlikede gördükleri an veya çeşitli nedenlerle yer değiştirdiklerine tanık olunur (Bozkurt ve Özgüzel, 2019: 817). Göç kavramı, insanların bulundukları yerden ekonomik, sosyal, siyasal ve kültürel nedenlerden dolayı başka bir yere hareket etmelerine verilen genel bir ad ve evrensel bir olay olarak tanımlanabilir. Göç olgusu, insanlığın en eski tarihlerinden bu yana süregelen ve gelecekte de devam edecek olan, dünyanın her yerinde görülebilecek bir durumdur (Koçak ve Terzi, 2012: 164).

Göç, insanın farklı coğrafyalar arasında bireysel yer değiştirme hareketi olarak görülebileceği gibi, özellikle savaş, kuraklık veya başka doğa olaylarının baskın olması durumlarında kitlesel düzeyde de gerçekleşebilmektedir (Şahin, 2001: 59). Kitlesel düzeyde bir göç hareketi için ekonomik ve siyasi nedenler ön plana çıkar. Ekonomik nedenlerin başında ilk Türklerde olduğu gibi kuraklık önemli bir sorundur. Siyasi nedenlere de Moğol istilası örnek gösterilebilir. Tüm bunlara günümüzde işsizlik, daha iyi hayat şartlarına sahip olmak, köyden kente, kentten köye göç ve emeklilik yıllarını sıcak bir sahil kasabasında geçirme isteğini de dâhil edersek göçün çok daha kapsamlı olduğu söylenebilir. 
Göç sözcüğü Türkçede hem fiil hem de isim olarak kullanılan bir sözcüktür. Türkçede köç (göç) / köç (göç-) sözcüğünden türetilen çok sayıda sözcük vardır. Türkçe Sözlükte göç sözcügü̈; "1. Ekonomik, toplumsal, siyasi sebeplerle bireylerin veya toplulukların bir ülkeden başka bir ülkeye, bir yerleşim yerinden başka bir yerleşim yerine gitme işi, taşınma, hicret, muhaceret: "Obalarının hâlâ arkası kesilmeyen göçleri devam etmekte idi." -S. Ayverdi. 2. Evden eve taşınma, nakil: "Her sene, zamanı gelince İstanbul'un mahallelerinde Boğaz'ın köylerine göçler başlardı." -A. Ş. Hisar. 3. Taşınma sırasında götürülen ev eşyaları. 4. hay. b. Kuşların, geyiklerin, yarasaların, bazı balık ve böceklerin mevsim, iklim, besin miktarı vb. ne göre çevre değiştirmeleri." (Türkçe Sözlük, 2011: 954-955) anlamlarında tanımlanmaktadır.

Batılı araştırmacılardan Sevortyan (1980: 88), isim olan göç (köç) sözcügünün anlamlarını; "1. Göç, göçebelik, kervan, savaş zamanında çadırların kurulduğu yer, küme, kamp. 2. Taşınma, seyahat (mecazî) ölüm. 3. Yer değiştirme, geçiş. 4. Göçebe hayat tarzı, göçebelerin eşyaları, ev mülkü. 5. Aile, karı, ev-maişet, avlu. 6. Sürgün yeri, kasaba, esaret. 7. Bir göçebelik yer kadar mesafe (25 km); 1 günlük mesafe. 8. Göçerli, geçerli. 9. Harem” olarak vermiştir. Nişanyan, "taşınma, taşınan yük" dediği göç sözcüğünün Eski Türkçe kökenli olduğu bilgisini verir (https://www.nisanyansozluk.com/?k=g\%C3\%B6\%C3\%A7). Burada Sevortyan göç sözcügü ile göçebelik arasında bağ kurmaya çalışırken, Nişanyan sözcüğün kökeni hakkında Eski Türkçeye dayanan bir bilgi vermiştir.

Fiil olan göç- (köç-) sözcüğü de Batılı araştırmacıların eserlerinde ele aldığ1 sözcüklerden biridir. Clauson (1972: 694) sözlüğünde sözcüğün anlamı, "ikâmetgâh değiştirmek, göç etmek, göçebe olmak ve mecazî anlamda ölmek (yani yaşadığımız bu dünyadan diğerine göç etmek)" şeklinde geçmektedir. Sevortyan, sözcüğün anlamlarını, "1. Göçmek, bir yerden başka bir yere geçmek, göç yapıp dönmek. 2. Taşınmak: ülke değiştirmek, yeni yere göçmek; yeni yere geçiş yapmak, bir yeri terk edip gitmek, yerleşkeyi, duraklanan yeri terk etmek, kampı sökmek, oturulduğu yerden ayrılmak, emigrasyon yapmak, migrasyon yapmak, ülke ülke gezmek, dolaşmak, (mecazî) ölmek. 3. Bir yerden başka yere araba üzerinde götürmek; satrançta - adım yapmak. 4. Kocaya gitmek, evlenmek (kız için). 5. Bir yeri araçla terk etmek, araca binip gitmek, hareket etmek. 6. Çökmek, yıkılmak, eskimek, tahrip olmak; açılmak (yapışmış bir şey için), düşmek (tırnak için). 7. Otlatmak. 8. Su ile dolmak. 9. Patlamak, kendiliğinden atış yapmak, coşkuya kapılmak" (Sevortyan, 1980: 89-90) olarak verir. Sçerbak, sözcügüü eski şeklini köç şeklinde 'göç, bir yerden başka yere geçiş’ olarak verirken, Pritsak, köç < kö:ç olarak vermiş ancak bunu kanıtlamamıştır. Räsänen'in çalışmasında köç köç- şekillerinin anlamları, 
türemişleri ve Fin-Ugor karşılaştırmaları ayrıntılı olarak yer alır. Doerfer'e göre ilk anlamı 'otlak değişimi' (yazlık ve kışlık değişimi)'dir (Atmaca, 2016: 848).

Köç (Göç) / Köç- (Göç-) sözcüğü Eski Türkçeden beri var olan bir sözcüktür (Eski Türkçe için bkz. Bayat ve Aliyeva, 2008: 118). Eski Türkçede "köç" ve "köç-“" şeklinde geçen sözcük günümüzde "k g" değişimi sonucu "göç, göç- " biçimlerinde varlığını devam ettirmektedir. Türkçenin en eski sözlüğü olan Dîvânu Lügâti’t-Türk’te de “köç” ve “köç-“ şekillerinde yer alan sözcük, Eski Türklerde özellikle bozkır yaşamının bir sonucu olarak ortaya çıkmış olmalıdır. "Göç, göç-" sözcüğü benzer şekil ve anlamlarıyla tüm tarihi ve çağdaş Türk lehçelerinde yerini almıştır. Türkçede göç/göç- sözcügünden türetilmiş çok sayıda sözcük vardır. Bunun temel sebebi yaylak ve kışlaklar arasında bozkır yaşam şeklinin benimsenmiş olması ve hayvancılığın birincil geçim kaynağ olmasıdır. Hayvancılık birincil geçim kaynağı olsa da Türk tipi göç faaliyetleri bünyesinde tarımı bulundurur.

\section{Göçebe}

Göçebe sözcüğü terim olarak üzerinde çok tartış1lan sözcüklerden biridir. Bu sözcüğe bakıldığı zaman Türkiye Türkçesi sözlüklerinde bu sözcüğe iki anlam yüklendiği görülür: "1. Değişik şartlara bağlı olarak belli bir yöre içinde çadır, hayvan ve öteki araçlarla yer değiştiren, yerleşik olmayan (kimse veya topluluk), göçer, göçkün: "Karakaçanları, sürüleriyle dă̆ dağ dolaşan göçebe çobanlarıdır." -A. Haşim. 2. Mevsimlere göre ülke veya yer değiştiren (hayvan)" (Türkçe Sözlük, 2011: 955). Özellikle birçok araştırmacı tarafindan Yörük/Türkmen grupları karşılamak için kullanılan bu sözcük, Türkçe Sözlükte olması hasebiyle olsa gerek, Türkiye Türkçesi ağızları söz varlığını bünyesinde barındıran Derleme Sözlüğ̈̈’nde bulunmamaktadır. Sadece Muğla yöresinde kullanıldığı tespit edilen "göçeber” (Derleme Sözlüğü, III, 2009: 2121) Derleme Sözlüğü’ne girmiştir.

Göçebe sözcüğü, Türkçenin ilk yazılı eserlerinden Köktürk Yazıtlarında yer almaz. Sözcük, Karahanlılar döneminde Kaşgarlı Mahmud tarafından yazılan Türkçenin ilk sözlüğü Dîvânu Lügâti't-Türk'te de kendine yer bulamamıştır. Göçebe, tarihi Türk lehçeleri olarak bilinen Köktürk Türkçesi, Eski Uygur Türkçesi, Karahanlı Türkçesi, Harezm Türkçesi, Kıpçak Türkçesi ve Çağatay Türkçesinin hiçbirinde geçmemektedir. Eski Anadolu Türkçesi metinlerinde de kendisine rastlanılamamıştır. Sözcük, bunlara ek olarak 1943-1957 yılları arasında bilim âlemine sunulan ve 13. yüzyıl ile 19. yüzyıl arasında yayınlanan 227 eserin taranmasıyla oluşturulan ve özellikle Eski Anadolu Türkçesinin söz varlığını bünyesinde barındıran Tarama Sözlüğü’nde de mevcut değildir. Özellikle Tarama Sözlüğü’nde göç merkezli “göç, göç ber-güç etmek, göç çekmek, göçer, göçerev, göçerevli (göçerevlü), göçeril, göçer oba, göç etmek 
(göç kllmak), göçgün, gö̧̧güncü (göçküncü), göç kon, göç kon etmek (göçüp konmak), göçkün, göçlük, göçmek, göçmel, göç tutmak, göçtük yurt, göçürmek (Tarama Sözlüğü, III, 2009: 1717-1723)" sözcükleri yer alırken hatta Adıyaman ağzında; "göçger: göçebe" (Telli ve Bulduk, 2018: 108) diye farklı bir sözcük mevcutken göçebe sözcüğünün yer almaması sözcügün çok kullanılmadığı ve sonradan türetildiği izlenimi vermektedir.

Göçebe sözcüğü için yapılan etimolojik tanımlara bakılacak olursa, Eyüboğlu sözcüğün "köçer oba (göçen ev)" dan türediğini ve köçeroba > köçebe > göçebe > göçebe şeklinde gelişim gösterdiğini bildirir. Eyüboğlu yazısının devamında konuyla ilgili "Eski Türklerde belli bir yerde uzun yaşama yoktu. Ulus çadırlarda yaşar, yazın yaylakta, kışın kışlakta otururdu. Evler de oba denen çadır biçimindeydi. Bu toplulukların, obaların yaz-kış konup göçmeleri nedeniyle, kendilerine konup göçen topluluk, konup göçen ev anlamında göçer oba denmiş daha sonraları orta sesler " $r$ " ve " $o$ " seslerinin düşmesiyle sözcük göçebe biçimine girmiştir. Keçübe, geçübe, kecübe biçimleri de var. Bu durumda köçer oba > köçübe > keçübe > göçübe > göçebe gelişmesi doğaldır" (Eyüboğlu, 1988: 139) der. Eyüboğlu'nun bu değerlendirmesinde çadırlara oba dendiği tespiti kesin değildir. Hiç bir eserde böyle bir anlamlandırmaya rastlanılamamıştır.

Ögel (1978), göçebe sözcüğüyle ilgili, dilimize Türkçe "göç-oba” veya Farsça "göç-ave"den yerleştiği söylenen göçebe kelimesi; hayvancilığa bağl1, hayvanları otlaklarda beslemek zorunluluğuyla yılın belirli dönemlerinde mevsime ve iklim şartlarına bağlı olarak yer değiştiren insan topluluklarını ifade etmektedir. Dilimizdeki "göçer-evli”, "göç-küncü” ve "konar-göçer" kavramları hep bu anlamda kullanılmıştır (Ögel, 1978: 5) demektedir.

Türk halkının geçmişten günümüze var olan kültürel yapısı birçok araştırmacı tarafından göçebe terimiyle karşılanmaktadır. Hatta ilk Türklerin ve özellikle Yörük/Türkmen grubun yaylak ve kışlaklar arasındaki göç faaliyetleri atlı göçebe Türkler şeklinde tanımlanmaktadır (Ögel, 1995; Gürbüz, 1997; Beşirli, 2003; Köse, 2005). Burada göçebe terimini kullananların bunu kavramsal bir zemine oturtarak tanım yaptıkları söylenemez. Burada daha çok araştırmacıların kendilerinden önce yapılan genel kabule uyarak bir tanım yaptıklarını söylemek daha doğrudur. Türkçeye yapılan çevirilerde de bu durum görülmektedir.

Yörük/Türkmen gruplar üzerine araştırmaları olan Mehmet Eröz, göçebeliği iki ana başlıkta toplamıştır. Bunlardan birisi tam göçebelik, diğeri ise yarı göçebeliktir. Tam göçebeliği de, yatay -sahra/ova- ve dikey -dağ- olarak ikiye ayırmıştır. Eröz (1991)'e göre yatay göçebelik, uzak mesafeler arasında cereyan eden ve daha ziyade Arap Yarımadası ve Kuzey Afrika gibi çöl bölgelerinde 
görülen göçebelik türüdür. Dikey göçebelik, yazın yüksek dağlar üzerindeki yaylalara, otlaklara, kışın kışlaklara göçmek şeklinde ortaya çıkan göçebelik türüdür. Yarı göçebelik ise, göçebelikten yerleşik hayata geçişte ara tip olarak tanımlanmıştır. Kışın köylerde çadır yerine ağaç, taş, tuğla, saz gibi evlerde oturulur, daha ziyade hayvancılıkla yürüyebilen hububat ziraatı yapılır; yazın ise, hayvanlar alınıp yaylalara çıkılır ve çadırda kalınır. Orta Asya'daki Türk aşiretlerinin önemli bir kısmı, İran'daki Kaşgaylar ve Türkmenler, Anadolu'daki Yörüklerin büyük bir çoğunluğu bu göçebelik modeline uymaktadır (Eröz, 1991: 71-72).

Baykara (2001), göçebe ve göçebelik terimiyle ilgili olarak, bir yerde karar etmeksizin hem zaman hem de mekânda hareket halindedirler. Senenin hemen her zamanını farklı yerlerde geçirebilirler, aynı yerde hem yaz hem de kış aylarını geçirebilmektedirler (Baykara, 2001: 63) biçiminde görüş bildirmektedir.

Göçebelik ve göçebe terimiyle ilgili yukarıda birçok tanım ve etimolojik değerlendirme verildi. Bu etimolojik değerlendirmelerde ve tanımlarda birlik yoktur. Biliyoruz ki Türk tipi göç faaliyetleri ile Arap tipi göç faaliyetleri ve Roman olarak da adlandırılan Çingenelerin göç faaliyetleri arasında farklılıklar vardır. Bu sebeple göçebe sözcüğ̈̈ne sadece etimolojik değil kavramsal açıdan da bakmak lazım. Göçebe sözcüğü Türkçe kökenli bir sözcük olabilir ama geçmişten günümüze seyredildiğinde anlamsal olarak Türk tipi göç faaliyetlerini tam olarak karşılamadığı görülür. Ayrıca göçebe sözcügünün yazılı kaynaklara girdiği yıllar 1800'lü yıllara tekabül etmektedir. En eski kaynaklarda, Eski Türkçede, Orta Türkçede, Eski Anadolu Türkçesinde, tarihi ve çağdaş Türk lehçelerinde bu sözcüğün geçmiyor olması sözcüğün özellikle Arap tipi göç faaliyetlerini karşılamak için ortaya çıkarılmış bir sözcük olma ihtimalini artırmaktadır. Çünkü bilinmelidir ki Türk tipi göç faaliyetleri düzensizlik içinde bir bilinmeze değil tam aksine önceden planlanmış bir şekilde otlakların olduğu yeredir. Bunun en iyi örneği Yörük/Türkmen gruplardır. Yörük/Türkmen gruplar önceden belli olan yaylaklar ve kışlaklar arasında göç faaliyetlerini sürdürmektedirler. Fakat Çingeneler ve Arap Bedevilerinin göç faaliyetleri belli bölgeler arasında yaz-kış değişen göç faaliyeti değildir. Öncelikle Çingenelerin göç faaliyetleri incelendiğinde onların göç faaliyetlerinin ticari amaçlı olduğu görülür. Bilindiği üzere bu insanlar belli bir bölgeye bağlı kalmadan ve işin ilginç yanı; bir sonraki duraklarının tam belirlenmediği bir silsile ile neredeyse tüm Asya ve Avrupa'yı dolaşmaktadırlar. Hatta bu nüfusun Balkanlar'da da belli bir nüfusa sahip olduğu görülür. Her ne kadar günümüzde daha yerleşik bir yaşam benimsemiş olsalar da hâlâ bir sonraki duraklarını bilmeden göç faaliyetlerini sürdürmektedirler. 
Göç merkezli yaşam tarzı Araplarda, Türklerden ve Çingenelerden daha farklıdır. Bir başka coğrafya olan Arap coğrafyasında "göçebe" ya da İngilizcedeki karşıllı̆ı ile "nomad" olarak ifade edilen topluluklar vardır. Arabistan yarımadasında Bedevi olarak adlandırılabilecek çöl göçebeleri mevcuttur. Kuzey Afrika'da da, Tuareg ya da Berberî örneklerinde olduğu gibi bu tarz hayatı benimseyen gruplar bulunmaktadır. Onlar da Kuzey Afrika'nın sıcak Büyük Sahra çölünde, kuzey-güney boyunca kat eden ticaret yolları üzerinde söz sahibidirler (Yılmaz ve Telci, 2010: 20). Bu iki grubun göç faaliyetleri ile Türklerin göç faaliyetleri farklıdır.

Bu kadar zengin olan ve her türlü olaya, nesneye ve sıfata farklı bir ad bulan Türkçenin Türklere has olan göç faaliyetleri ile diğer gruplara ait olan göç faaliyetlerini aynı sözcüklerle karşılaması çok zayıf ihtimaldir. Bu durum günümüz için de geçerlidir. Yatay göçebelik, dikey göçebelik gibi bir adlandırma dili kullanan halk için zor ve sonradan üretilmiş bir karşılıktır. Ayrıca günümüzde Türk tipi göç faaliyetlerini devam ettiren Yörük/Türkmen grupların kendilerini adlandırırken yatay, dikey, dağ göçebeliği gibi adlarla adlandırmadıkları görülür. En eski kaynaklarda göçebe sözcüğünün geçmemiş olması ve özellikle Arap-Fars toplumuyla ikili ilişkilerin artması sonucu Anadolu sahasında bu sözcüğün ortaya çıkmış olması, sözcüğün kavramsal olarak Arap tipi göç faaliyetlerine benzer göçleri karşılamak üzere kullanıldığ fikrini artırmaktadır.

Göçebe sözcüğünün etimolojik kökenine bakıldığı zaman farklı değerlendirmelere rastlanır. Özellikle sözcügün "köç (göç)" ve "oba" sözcüklerinden türediği düşüncesi etrafında birçok araştırmacının birleştiği görülür. Ama hem fiil olan "köç- (göç-)" hem de isim olan "köç (göç)" fark etmeksizin "köç (göç)" ve "oba" sözcüklerinin herhangi bir ek almadan birleşerek yeni bir sözcük oluşturması dil kurallarına aykırıdır. Göçebe, "köç(göç-)" fiiline eklenen “+Ar" geniş zaman sıfat fiil ekiyle "köç-er oba > göç-er oba” biçiminde meydana gelebilir. Bu ihtimal güçlü bir ihtimal olarak düşünülebilir çünkü akıc1 " $r$ " ünsüzü düşme eğiliminde bir ünsüzdür ve sözcük zamanla "köçer $o b a>$ göçer oba > göçeba > göçebe" şekline dönüşmüş olabilir. Nişanyan da yaptığ 1 etimolojik değerlendirmede (Nişanyan, https://www.nisanyansozluk.com/?k=g\%C3\%B6\%C3\%A7ebe) benzer durum üzerinde durmuştur. Nişanyan'a göre de sözcük Türkçe kökenlidir ve "köç(göç-)" fiili ile "oba" isminin ortasına eklenen "+Ar" sıfat fiil ekinin birleştirici özelliği sonucu "köç-er oba (göçer oba)" olarak meydana gelmiştir. Bu durum dil kurallarına uygundur ama Eski ve Orta Türkçe dönemlerinde bu şekilde sözcük oluşturma biçiminin çok tercih edilmemesi ve "oba" sözcügünün başka hiçbir kullanımda şekil değişimine uğramamış olması, sözcügün böyle bir geçmişinin olduğunu kesin bir şekilde söyleyemememize neden olmaktadır. Özellikle Eski ve Orta Türkçe dönemleri, birleşik sözcük oluşturmanın çok 
etkili olmadığı dönemlerdir. Birleşik sözcükler daha çok Osmanlı ve Cumhuriyet dönemlerinde yabancı sözcüklere Türkçe karşılık üretmek amacıyla tercih edilmiş bir yöntemdir. Göçebe sözcüğü yukarıdaki bahsedilen duruma ek olarak "köç- (göç-)" fiiline eklenen "-An" sıfat fiil ekiyle birlikte "köç-en oba > göçen oba" biçiminde de oluşmuş olabilir. Ama bu ihtimal "köç-er oba (göçer oba)" biçimine göre daha zayıf bir ihtimaldir. Çünkü Türkiye Türkçesi incelendiği zaman "+Ar" sıfat fiili ile ekleşerek oluşan birleşik sözcüklerin daha çok tercih edildiği görülür. Ayrıca düşme eğilimindeki akıcı " $r$ " ünsüzün düşme ihtimali de göz önüne alınırsa bu yöndeki düşünce daha ağır basmaktadır. Ama sözcüğün eski kaynaklarda kendine yer bulamaması ve sıfat fiil tabanlı birleşik sözcüklerin özellikle Osmanlı son dönemleri ile Cumhuriyet dönemlerinde daha çok tercih edilmesi sözcüğün bu şekilde türeyip türemediği noktasında birçok şüphe barındırmaktadır. Genel değerlendirme kısmında bu şüpheler de dikkate alınarak nihai bir değerlendirme yapılmaya çalışılacaktır.

Göçebe sözcüğünün kökeniyle alakalı ikinci bir ihtimal sözcügün isim kökenli "köç (göç)" sözcüğü ile "oba" sözcüğünün oluşturduğu belirtisiz isim tamlaması sonucu ortaya çıkmış olabileceğidir. Bu düşünceye göre sözcük "köç oba-sl (gö̧ oba-sl)" biçiminde "oba" ismine eklenen 3. teklik şahıs iyelik eki “sI, -sU” ile birlikte birleşik sözcük hüviyeti kazanmış olabilir. Ama bu ihtimal diğer ihtimallere göre daha zayıftır.

Göçebe sözcüğünün etimolojisiyle ilgili karşımıza çıkan drdüncü değerlendirme sözcüğün "köç- (göç-)" fiiline eklenen "+mA" isim fiil ekinin ekleşmesi sonucu ortaya çıktığ yönündedir. Sözcük, bu değerlendirmeye göre "köçme > göçme > göçeme > göçebe" şeklinde ortaya çıkmıştır (Gülensoy, 2011: 374). Bu etimolojik değerlendirme yukarıdaki üç değerlendirmeye göre çok daha olasıdır. Türkçede "m $\sim$ b" değişimi dil kurallarına uygun bir değişimdir. Fakat bu etimolojik değerlendirmenin de doğruluğu kesin değildir.

Göçebe sözcügünün etimolojisiyle ilgili üzerinde durulması gereken dördüncü ihtimal sözcügün Türkçeden Farsçaya geçen "köç (göç)"ün daha sonra aldığ1 yeni şekille Türkçeye geri dönmesidir. Farsçada "köç (göç)" sözcügüunün "koc, kuc, kûç" şeklinde kullanıldığ 1 kaynaklarda yer almaktadır. Mütercim Âsım Efendi'nin Burhân-1 Katı isimli eserinde; "kûç: Bir yerden aher yere nakl manasındadır ki göçmek, göç etmek tabir olunur." (Mütercim Âsım Efendi, 2009: 455) biçiminde yer almaktadır. Farsçada bir de cemaat, aşiret anlamına gelen "abe" sözcüğü vardır ve Osmanlı Türkçesinde de kullanılmıştır. Osmanlı Türkçesi döneminde Arap ve Fars tipi göç faaliyetlerini karşılamak için sözcük, Farsçadan tekrar "kuc-abe, koc-abe, kûç-abe" biçiminde geri alınmış ve zamanla "kucabe > köcabe > köçabe > göçabe > göçebe" şeklinde kendisine kullanım alanı oluşturmuş olabilir. Bunun yanında sözcük direkt Türkçedeki "köç (göç)" sözcüğüne Farsça kökenli "cemaat, aşiret, topluluk" 
anlamlarına gelen "abe"nin eklenmesi şeklinde de vuku bulmuş olabilir. Ayrıca Farsçada; "kecâbe, kecebe, kecâve: Devenin üstüne konan oturulacak bir çeşit tahtırevan" (Mütercim Âsım Efendi, 2009: 409) şeklinde Osmanlı Türkçesinde de kullanılan bir sözcük vardır. Bu sözcük, deveyle yapılan her türlü göçte devenin üzerine konan ve insan taşımak için kullanılan araç anlamındadır. Bu sözcük de Türkçede "göçebe" biçiminde kullanım alanını genişletmiş olabilir. Ama bu ihtimal çok düşük bir ihtimaldir. $\mathrm{Bu}$ değerlendirmeler, göçebe sözcüğünün Türkçeden Farsçaya geçen "köç (göç)" sözcüğünün tekrar Farsçadan geri alınırken Farsça kökenli olan ve aşiret, topluluk anlamına gelen "abe, âbe, ave" sözcüğü ile birleşmesi sonucu ortaya çıkmış olabileceği ihtimalini artırmaktadır. Aşiret, topluluk anlamına gelen "abe, âbe, ave"nin "köç (göç)" sözcüğü ile birleşmesi Türkçe kökenli "oba"nın "köç (göç)" ile birleşmesinden daha yakın bir ihtimaldir. Göçebe sözcüğüne bu açıdan da bakilmalıdır.

Tüm bunlar toplandığ 1 zaman özellikle göçebe sözcügünün Türkçe kaynaklarda kendine çok yer bulamadığını söylemek yerinde olacaktır. Sözcüğe birçok araştırmacı kavramsal açıdan yaklaşmamış, kendisinden önceki söylenenleri tekrar etmiştir. Ama özellikle sözcügün Tarama ve Derleme Sözlüğü'nde yer almaması, üzerinde düşünülmesi gereken bir durumdur. $\mathrm{Bu}$ durum göçebenin İngilizce "nomad" ve Osmanlı Türkçesi dönemindeki "bedevi” sözcüklerine karşlık türetilmiş olduğu ihtimalini artırmaktadır. Çok zengin bir dil olan Türkçenin, yaylak ve kışlaklar arasında hem hayvancılık hem de tarım yaparak geçimini sürdüren Yörük/Türkmen grupla, bedevi yaşamı süren Araplar vb. toplulukların yaptığı göç faaliyetlerini aynı adla adlandırması zayıf bir ihtimaldir. Bu sebeple tüm bunlardan yola çıkılırsa göçebe sözcüğü Türkçe kökenli veya yabancı kökenli bir sözcük olabilir. Türkçede kullanılan çok fazla yabancı sözcük vardır. Yani göçebe sözcügünün yabancı kökenli olması kullanımını etkileyen bir durum değildir. Ama kavramsal olarak bakıldığ1 zaman, Anadolu'da yaşayan Yörük/Türkmen grubun kendilerini göçebe olarak nitelememeleri, sözcüğün kaynaklarda kendine çok fazla yer edinmemesi gibi durumlar, göçebe sözcügünün Türk tipi göç faaliyetlerini tam olarak karşılayan bir sözcük olmadığını gösterir. Bu sebeple denilebilir ki göçebe sözcüğü, düzensiz bir şekilde olan, bir sonraki gideceği yer kesin olarak bilinmeyen Çingeneler ve özellikle de çöl bölgelerinde göçlerini sürdüren Araplar vb. topluluklar tarafından yapılan göç faaliyetlerini karşılamak için türetilmiş bir sözcük izlenimi vermektedir. Sözcüğe bu açıdan bakılarak anlam yüklemesi yapılması daha yerinde olabilir.

\section{Göçer}

Göçer sözcüğü Türkçe Sözlükte, "göçebe” (Türkçe Sözlük, 2011: 955) karş1lığı ile verilmektedir. Buradan sözcügün Türkçe Sözlükte göçebe ile aynı 
anlamda yani; "1. Değişik şartlara bağlı olarak belli bir yöre içinde çadır, hayvan ve öteki araçlarla yer değiştiren, yerleşik olmayan (kimse veya topluluk), göçer, göçkün: "Karakaçanları, sürüleriyle dă̆ dağ dolaşan göçebe çobanlarıdır." -A. Haşim. 2. Mevsimlere göre ülke veya yer değiştiren (hayvan)" (Türkçe Sözlük, 2011: 955) biçiminde geçer. Göçer sözcüğü, 13. yüzyıl ile 19. yüzyıl arasında kaleme alınan 227 eserin taranmasıyla oluşturulan ve özellikle Eski Anadolu Türkçesinin söz varlığını bünyesinde barındıran Tarama Sözlügü̈nde; "göçer: Gezer, bir yerde durmaz, güçebe” (Tarama Sözlüğü, III, 2009: 1717) şeklinde karş1lı bulur. Tarama Sözlüğünde sözcüğün geçtiği eserlere bakıldığı zaman öncelikle 16. yüzyılda (1597) Trabzonlu Âşık Mehmet bin Hafız Ömer'in kaleme aldığı Menazir-ül Avalim isimli Rumeli ve Anadolu şehirlerine ait bilgiler veren kitap karşımıza çıkar. Günümüzde Süleymaniye Kitaplığının Halet Ef. Bölümünde 616 numara ile kayıtlı bulunan 690 sayfalı nüshanın taranması sonucu sözcük tespit edilmiştir. Sözcük, kitabın ilgili yerinde "Ve tekrur iki kısımdır, bir kısmı hasindır, Müdünde sakin olur; ve bir kısmı bevadi² de göçer oluptur.” (Tarama Sözlügü, III, 2009: 1717) biçiminde şehirde ve çöllerde/sahralarda yaşayan iki kısım insan yaşayışı hakkında bilgi verirken geçmektedir. Burada çöl olarak bahsedilen ova olmalıdır. Sözcük yine 16. yüzyılda Âşık Paşazade Derviş Ahmet Âşıkî bin Yahya tarafindan, yer yer manzumelerle de süslenerek meydana getirilen ve Osmanlı saltanatının kuruluşundan II. Bayezid çağının yarısına kadar olan zamanı anlatan Tevârih-i Âl-i Osman (Aşık Paşazade Tarihi) isimli eserde de " Atasi Orhan Gazi'ye haber gönderdi kim devletinle himmetinle Rum-ili feth olunmağa sebeb olundl. Kâfirler gâyet zebundur. İmdî şöyle ma 'lum ola kim, bu tarafdan feth olunan hisarlara vilâyetlere ehl-i İslamdan çok âdem gerekdir. Bu feth olan hisarlar içün içine komağa ve hem yarar gaziler gönderin. Orhan Gazi dahi kabul etdi. Vilâyetine göçer kara Arap evleri gelmişti, anları sürdü, Rumeline geçirdi. Birinci zaman Gelibolı nevâhisine sâkin oldılar." (Tarama Sözlüğü, III, 2009: 1717; Âşık Paşazade, 2003: 109, 376-377) şeklinde geçmektedir. Sözcügün yer aldığı bu iki eserde dikkat çeken konu, ilk eserde "çöllerde göçer oluptur" ve "göçer kara Arap evleri” ifadesidir. Birincide çöllerde göçer olmuşlardır ile anlatılan gerçek çöller değil Anadolu'daki ovalar olmalıdır. İkinci eserde "göçer kara Arap evleri” olarak ifade edilen Karesioğulları Beyliği'dir. Osmanlı döneminde Karesi Beyliği için "göçer evler, kara Arap" gibi adlandırmalar yapılmıştır. Burada anlatılan göçer kara Arap evleri Osmanlı tarafından Orhan Bey zamanında dışa dönük iskân kapsamında Rumeli'ye göç ettirilen Karesi halkıdır. Karesi halkı Osmanlı tarafından zorunlu olarak önce Gelibolu yöresine daha sonra da Hayrabolu'ya göç ettirilmiştir. Bu halkın genel yapısına bakıldığg zaman Türk tipi göç faaliyetlerinde bulunan yani hayvancılıkla geçinen ve yaylaklar-kışlaklar arasında göç eden bir halktır.

${ }^{2}$ bevadi: Sahralar, çöller. 
Göçer sözcüğüne anlamsal açıdan bakıldığı zaman sözcük özellikle Anadolu Yörük/Türkmen grubunu ifade etmek için kullanılmaktadır. Özellikle 16. yüzyıla ait olan ve 14. yüzyılda Orhan Bey zamanında Rumeli'ye iskan edilen Karesioğulları Beyliği hakkında bilgiler veren Âşık Paşazade Derviş Ahmet Âşıkî bin Yahya'nın Tevârih-i Âl-i Osman (Aşık Paşazade Tarihi) isimli eserinde Karesi halkı için "göçer evler, kara Arap" gibi ifadelerin kullanılmış olması göçer'in çok daha eski tarihlerde hayvancılıkla uğraşan ve yaylaklarkışlaklar arasında göç eden Anadolu halkını ifade etmek için kullanıldığ 1 yönündeki fikirleri kuvvetlendirmektedir. Sözcügün anlamsal boyutuyla ilgili Kutlu (1987); "Yaşadıkları bölgelere göre Türkmen, Yörük ve göçer adlarıyla bilinen Anadolu göçer toplulukları, hayvancılığa bağlı ekonomileriyle, yerleşik hayat ile göçebelik arasında ara şekiller olarak kabul edebileceğimiz bu hayat tarzının izlerini taşıyan topluluklardır" (Kutlu, 1987: 3) bilgisini vermektedir. Burada önemli olan Anadolu Yörük/Türkmen grubun göçer olarak da ifade edilmesidir. $\mathrm{Bu}$ toplulukların kendilerini ifade ederken "biz göçer'iz." biçiminde nitelemeleri bu sözcüğü kullandıklarını gösteren önemli detaylardan biridir.

Anadolu Yörük/Türkmen grubun göçer olarak ifade edilmesi önemli bir husustur. Bu durum bazı çalışmalarda da dile getirilmektedir. Spooner'in de ifade ettiği gibi; "Avcı-toplayıcılar da göçebe bir topluluktur. Ancak onlar üretmeyen ve kendi ihtiyaçlarını karşılamak için göç eden gruplardır. Hâlbuki hayvancı göçerler kendileri için değil, hayvanlarının ihtiyaçları için göç ederler. Hayvancı göçerlerin hayatları, hayvanlarının doğal ihtiyacına bağlı olarak form almıştır. Tarih boyunca otlaklar ve hayvanlar, göçün şeklini ve güzergâhını da belirlemiştir" (Spooner 1972: 122-124; Saydam, 2009: 28). Hayvanları için yaylaklar ve kışlaklar arasında göç faaliyeti yapan Yörük/Türkmen grubun Osmanlı içindeki durumuna dikkat çeken Şahin (2006) ise; “Anadolu’ya gelen Türkler, Osmanlı Devleti döneminde 'Türkmen' adının yanında 'Yörük' olarak da isimlendirilmiştir. Zaman zaman birbirlerinin yerine kullanılan bu iki kelimeyi taşıdıkları anlamlar bakımından kesin çizgilerle birbirinden ayırmak çok güçtür. Türkmenler ve Yörükler olarak anılan bu gruplar yaşam tarzlarının bir geleneği olarak 'konar-göçer', 'konar göçer Yörük', 'göçer Yörük', 'göçer evli', 'göçkün', 'göçküncü', 'göçerler' ve 'göçebe' gibi isimlerle de anılmışlardıı” (Şahin, 2006: 61) der. Erinç (1973) de benzer duruma vurgu yaparak; "13. yüzyıl ortalarında Moğol baskısı sonucunda Doğu Anadolu sınırlarından Batı Anadolu ve Orta Anadolu'ya uzun süren göç dalgalarıyla gelmeye ve burayı yurt edinmeye başlayan Oğuz Türkleri, yerleşik hayata geçtiği ve yerleşik kültürlerin ağır bastığı Selçuklu ve Osmanlı Devleti dönemlerinde de, 'Türkmen' ve 'Yörük' gibi isimler altında toplanan büyük bir Türk kitlesi olarak hayat tarzını devam ettirmiştir. Anadolu göçer kültürünün dayandığı temellerden biri de, Anadolu Coğrafyası'dır. Bu coğrafya, Yörük kültürünün Anadolu'daki varlığını sürdürebilmesinin temel kaynağı olmuştur. 
Coğrafi özellikleri hep aynı olmasına rağmen tarihte daha önce Anadolu'da hayvancılığa dayalı bir göçebe kültürü izlenmemiştir" (Erinç, 1973: 24) demektedir.

Göçer ve göçerlik kavramını aşağıdaki gibi ifade etmek, sözcüğün kavram alanını kavramak açısından önemlidir. Anadolu Yörük/Türkmenleri saf göçer olarak ifade edilmelidir. Saf göçerliğin en önemli özelliklerini aşağıdaki şekillerde sıralayabiliriz (Khazanov, 1986: 85-87; Akt. Ürker ve Çobanoğlu, 2014: 155):

Göçerlik ekonomik faaliyetin şeklidir.

En yaygın karakteri, sürülerin alıkoymaksızın bütün bir y1l boyunca otlaklarda dolaştırılmasıdır.

Göçer ekonomisi, göçe karşıt olarak, belirli otlak bölgelerinin sınırları içinde göçer ekonomisinin taleplerine uygun döngüsel mevsimlik hareketliliğe dayanır.

Nüfusun tamamının ya da büyük bir kısmının göçer hareketliliğe katılımı söz konusudur.

Geçimin, ihtiyaçların gereklerine göre üretimin yönlendirilmesi, yani ihtiyaca göre üretim yapılması söz konusudur.

Anlam ve kavramsal açıdan ele alınan göçer kavramına etimolojik açıdan bakıldığında, göçer kavramının Türkçe kökenli olduğu net şekilde görülmektedir. Sözcük, Tuncer Gülensoy'un Köken Bilgisi Sözlüğü’nde; "göçer: göçebe. < göç - er" (Gülensoy, 2011: 374) biçiminde gösterilirken, İsmet Zeki Eyüboğlu'nun Türk Dilinin Etimoloji Sözlüğü’nde; “göçer: (Tr. göçmek’ten < göç-e-r): sürekli göçen, göçebe, yazın yazlıkta kışın kışlıkta konaklayan kimse, topluluk, oba” (Eyüboğlu, 1988: 139) biçiminde izah edilmektedir. Göçer, incelemelere göre Türkçe kökenli 'köç- (göç-)' fiiline sıfat fiil eki "+Ar"ın eklenmesi sonucu oluşmuştur. Göçer, ilk örneklerde "göçer oba, göçer evlü, göçer-konar (halk, oba, toplum)" biçimlerinde sifat görevinde kullanılmıştır. Zamanla sözcük ad görevi üstlenerek "göçer, göçerlik" şeklinde kalıcı ad haline gelmiştir.

Göçer sözcüğünün etimolojik geçmişiyle ilgili elde edilen en eski veriler ise Eski Türkçe dönemine ait olan Köktürk harfli metinlerdir. Konargöçer sözcüğünü açıklarken de değinilen Uygur dönemi metinlerinden Taryat-Terhin Yazıt1, "göçer" sözcügünün ilk görüldüğü yerdir. Uygur Kağanı Moyun-Çor tarafından diktirilen bu eser, 1970 senesinde Moğolistan'da Tarbagatay Dağları'nın $2 \mathrm{~km}$ güneyinde N. Serodjav ve V.V. Volkov adlı iki arkeolog 
tarafından bulunmuştur. Sadettin Gömeç (bkz. Gömeç, 1995: 71)'in de ifade ettiği üzere yazıtın dikiliş tarihi 753 yılına kadar götürülebilmektedir. Yazıtın Batı tarafının dördüncü ve beşinci sütununda şu ifadeler yer almaktadır (Gömeç, 1995: 74):

4- tört bulungdakı bodun iş güç ebirür yagım bölük yok boltı ötüken eli tegresi ikin ara 1lgam tarıglagım sekiz selenge orkun togla sebintürdü. kargu burgu ol yirimiq subıniın konar köçer ben

Türkçesi: dört taraftaki halklar (benim) işimi gücümü görürler. Düşmanım Bölük yok oldu. Ötüken ülkesi (ve) çevresi, ikisi arasında tarlalarım; SekizSelenge, Orkun, Togla, Sebintürdü, Kargu (ve) Burgu yerlerimde (ve) sularımda konar göçerim,

5- yaylagım ötüken kuzı kidin uçı tez başı öngdüni kanyuy künüy ... . 1lgam ötüken yiri ongı tarkan süy yagı bodunkı kagangı birigerü uçı altun yış kidin uçı kögmen ilgerü uçı \{KadırkanYış\}

Türkçesi: Yaylam Ötüken’in kuzey-batı ucu Tez-Başı, doğusu Kanyuy (ve) Künüy (nehirleri), tarlalarım Otüken bölgesi, kuzeyi Tarkan Süy düşman halka (ve) kagana, güney ucu Altun-Yış, batı ucu Kögmen, doğu ucu \{KadırkanYış\}

Tespitlerden yola çıkılırsa Uygurlar dönemini anlatan Köktürk harfli ilk metinlerde "göçer" sözcüğü "kon-" fiiliyle birlikte geniş zaman şeklinde "konar köçer ben (konar göçerim)" olarak yer almaktadır. Yazıttan hareketle görüldüğü üzere Uygur dönemi ve öncesi ilk Türkler, yaylak-kışlak temelli yarı-yerleşik bir hayat tarzını benimsemişlerdir. Bu metinde de belirtildiği üzere ilk Türklerde meçhul, gelişi güzel, düzensiz bir göç faaliyeti yoktur ve yaylak, kışlak sözcükleriyle birlikte aynı metinde 'tarlglag (tarla)' sözcüğü de yer almaktadır. Göçer sözcügüne "konargöçer" sözcüğüyle birlikte bakmak ve buradan hareketle daha geniş bir anlam yüklemek yerinde olacaktır.

\section{Göçer evli/evlü}

Göçer evli/evlü sözcüğü yaylak ve kışlaklar arasında çadırla gezen Yörük/Türkmen grup için kullanılan bir terimdir. $\mathrm{Bu}$ terim, Tarama Sözlüğü'nde; "Çadırla yer yer gezen, göçebe hayatı yaşayan insanlar" (Tarama Sözlüğü, III, 2009: 1718) biçiminde geçmektedir. Bu terim, Osmanlı kayıtlarında özellikle 15.-16. yüzyıl eserlerinde geçmektedir. 18.-19. yüzyıla ait bazı eserlerde de göçer evli/evlü terimine rastlanmaktadır. Sözcük, Hadidi Tarihi'nde Anadolu Selçuklu Devleti hükümdarlarından Süleyman Şah ile ilişkilendirilerek "Süleyman Şah o kavmin hanı imiş Göçerevlüleriñ sultanı imiş" (Hadidi, 1523: 29; Akt. Tarama Sözlüğü, III, 2009: 1718) biçiminde iken Tevârih-i Âl-i Osman’da; "Süleymân Şâh Gāzi hayli bahâdurluklar itdi. Bu 
Rûm'uñ taglarından ve derelerinden incindiler. Göçer evlerüñ tavarı dereden ve depeden incinür oldl. Gine Türkistân'a azm itdiler. Geldükleri yola gitmediler." (Dülger, 2012: 1071) biçimindedir ve yine Osmanlı dönemi Şeriye Sicilleri'nde "Ardavan ve Kaşıkçı cemâatı âdem gönderip şöyle arz eylediler ki bunlar göçerevlü Haymana'dan olup Koçhisar kazasına müteallık kurâda yazılı raiyet olmayıp" (Şeriye Sicilleri, A. XVI. 1, 118; Akt. Tarama Sözlüğü, III, 2009: 1718) biçiminde geçer. Sözcük, 18. yüzy1l eserlerinden Kanun-ül Edeb Tercümesi'nde, "el-vesut: Kilimden veya hasirdan bulup 'yaptıklarl ev, göçerevlileriñ evleri gibi” şeklinde yer alırken, 18.-19. yüzyıl sözlükçülerinden Mütercüm Asım Efendi'nin “el-Okyânûsu'l-Basît fî Tercemeti'l-Kâmûsi'lMuhît (Kâmûsu'l-Muhît Tercümesi)" adlı eserinde cemaat, topluluk anlamına gelen "haltat" sözcüğünün açıklamasında; "el-haltât: (hâ'nın fethiyle) Yurttan yurda konup göçer olan taife-i insaniye denir ki göçer evli tabir olunur. Türkmenler ulus tabir ederler, yakalu” (Mütercim Âsım Efendi, 2013: 823) olarak yer alır. 15. yüzyıl sonlarında kaleme alınan ancak kullandığı kaynaklar hasebiyle erken Osmanlı dönemine ilişkin önemli bilgiler içeren "Aşı Paşazâde Tarihi"nde Menemen ovasında kışlayan bir grup Saruhan Yörük'ü 'göçer' ve 'göçer evli' ifadeleriyle şu şekilde izah edilir: "Anı beyan ederim ki Saruhan İinin göçerhalkı vardı 'Menemen ova'sinda ksşlardl ve ol iklimde tuz yasağı vardı. Onlar ol yasă̆ kabul etmezdi. Bayezid Han'a bildirdiler oğlu Ertuğrul'a haber gönderdi o göçer evleri önat zapt ile yarar kullarina ısmarlayasin Filibe yöresine gönderesin. Ertuğrul dahi atasının sözünü kabul etti ol göçer evleri Filibe yöresine gönderdi.” (Âşı Paşazâde, 2003: 406). Burada geçen göçer evler kavramı, göçer evli/evlü teriminin Türk tipi göç faaliyetleriyle olan ilişkisi açısından da son derece önemlidir. Tüm bu eserlerden hareketle denilebilir ki sözcük, 15.-16. yüzyıldan sonra eserlere girmek kaydıyla yurttan yurda konup göçen Yörük/Türkmen halkını tanımlamak ve anlatmak için Türkçede kendisine yer bulmuştur. Göçer evli/evlü sözcüğü, 15.-16. yüzyıldan önce kullanılıyor da olabilir lakin özellikle 15.-16. yüzyıldan sonra direkt madde başı olarak veya madde başlarının tanımı yapılırken yazılı dilde yer edinmeye başlamıştır.

Yukarıda anlatılan ve göçer evli/evlü sözcüğü ile ilişkilendirilen halkların tamamı Selçuklu ve Osmanlı zamanında Anadolu'da yaşayan Yörük/Türkmen halklarıdır. Bu halklar genel olarak yaylaklar ve kışlaklar arasında yurttan yurda konup göçen ve çadırlarda yaşayan halklardır. Kanun-ül Edeb Tercümesi'nde tanımı "Kilimden veya hasırdan bulup yaptzkları ev, göçerevlileriñ evleri gibi" şeklinde yapılan "el-vesut" sözcüğü tanımlanırken geçen "kilimden ve hasırdan bulup yaptıkları ev" biçimindeki evler, Yörük/Türkmen gruba ait olan çadırların ve topak evlerin kenarına hasır otu (kamış, saz)'ndan örülen çitlerle yapılan ve üzerine ala kilimler örtülen evler olmalıdır. Hasırdan yapılan evler tanımının bu bapta düşünülmesi lazım. Osmanlı dönemi Şeriye Sicilleri'nde yer alan ve "Haymana - Koçhisar" arasında konup göçen Ardavan ve Kaşıkçı 
cemaatleri de yine topluluk halinde yaşayan Yörük/Türkmen grubu anlatmaktadır.

Göçer evli/evlü sözcüğüne anlamsal açıdan bakılacak olursa sözcügün tüm kaynaklarda Türk tipi göç faaliyetlerini anlatmak için kullanıldığı görülür. En temel anlamı "göçer evli/evlü" sözcüğü ile bağdaştırılan toplumların yıl içinde mevsimlere göre sürekli yer değiştirmeleridir. Göçer evli/evlü terimi ile bağdaştırılan halkların özelliği anlatılırken kullanılan "Hayvanların beslenmesi için gerekli olan otlak ve su ihtiyacını karşılama endişesi, hayvan beslemeye dayalı üretim tarzını benimseyen bu insanların belirli bir bölgeye yerleşmesini engellemiş ve çok hareketli bir yapıya sahip olmalarına neden olmuştur.” (Karataş, 2017: 131) şeklinde yapılan tanım da bu sözcügün anlamsal olarak Yörük/Türkmen grubu karşılamak için kullanıldığını gösterir. Sözcüğün anlamsal yapısını ortaya koymak için Bahaettin Ögel'in Türk göçerevliliğgin şekilleri şeklinde izah ettiği yapıya da değinmek gerekir. Ögel (1985), Türk Kültür Tarihine Giriş isimli eserinde Türk göçerevliliğinin şekillerini tam göçerevlilik, yarı göçgüncüler ile devlet ve ordu düzeni ile hayvancılık olarak üçe ayırmaktadır. Tam göçerevlilik, Moğolistan ve Altayların kuzeyinde yaşayan Türk göçgüncüleri geniş kitleler halinde yaşıyor ve hayvanları için yeni otlaklar ve sular arıyorlardı. Hem ziraat hem de hayvancılığa dayalı bir ekonomiye sahip olduğu görülmektedir. Yarı göçgüncüler ise "köy-yayla" hayatı olarak da tanımlanabilir. Ancak yalnız köyler değil şehirler de yaylasız kalmazdı. Devlet ve ordu düzeni ile hayvancilık ise hükümdar ile ordunun bizzat hayvan beslemeye katılmasıdır (Ögel (1985: 44-51) diyerek terimleri izaha çalışır. Ögel (1985) burada Türk tipi göç faaliyetlerini yapan halkları kendi içinde tam, yarı gibi bölümlere ayırmış olsa da bu faaliyeti yapan halkları göçer evli olarak tanımlaması sözcüğün anlamsal çerçevesinin anlaşılması açısından önemlidir. Kaynaklardan elde edilen veriler ışığında anlaşılan odur ki göçer evli/evlü ile anlatılmak istenen, ev olarak adlandırılan çadırlarını yanlarında taşıyan ve göç faaliyetlerinde bulunan Yörük/Türkmen grubudur.

Anlamsal ve kavramsal açıdan ele aldığımız göçer evli/evlü sözcüğüne etimolojik açıdan bakıldığında, sözcügün Türkçe kökenli olduğu net şekilde görülmektedir. Sıfat tamlaması olarak oluşturulan sözcüğün göçer kısmı Tuncer Gülensoy'un Köken Bilgisi Sözlüğü'nde; "göçer: göçebe. < göç - er" (Gülensoy, 2011: 374) biçiminde gösterilirken, İsmet Zeki Eyüboğlu'nun Türk Dilinin Etimoloji Sözlüğü’nde; “göçer: (Tr. göçmek’ten < göç-e-r): sürekli göçen, göçebe, yazın yazlıkta kışın kışlıkta konaklayan kimse, topluluk, oba" (Eyüboğlu, 1988: 139) olarak izah edilmektedir. Sözcügün göçer kısmı örnekte görüldüğü üzere Türkçe kökenli 'köç- (göç-)' fiiline sıfat fiil eki “+Ar”'1n eklenmesi sonucu oluşmuştur. Göçer bu örnekte olduğu üzere bazı isimlerle birleşerek " göçer oba, göçer evli/evlü, göçer-konar (halk, oba, toplum)" biçimlerinde sıfat görevinde kullanılmıştır. Zamanla göçer terimi ad görevi 
üstlenerek "göçer, göçerlik" şeklinde kalıcı ad haline gelmiştir. Göçer sözcüğüne benzer kullanımlar Türkiye Türkçesi yazı dilinde "yazar, çizer, döner, keser, yeter, tutar, geçer, gider” sözcüklerinde de görülmektedir. Burada göçer ile birlikte yer alan ev sözcüğü ve bu sözcüğe eklenen " $+11,+l i,+l u,+l u ̈$ ” isimden isim yapım eki de Türkçe kökenli gramer unsurlarıdır. Köktürk Türkçesinde " $e b$ ” (Ergin, 2006: 92), Uygur Türkçesinde "eb, ev, ew, ev bark" (Eraslan, 2012: 566, 569) şekillerinde yer alan sözcük, Karahanlı Dönemi eserlerinden Dîvânu Lügâti’t-Türk’te “ev, ew: Oğuzlarda ve onları takip edenlerde ev, çadır" (Kaşgarlı Mahmud, 2018: 649, 650) şeklinde geçmektedir. Eski Türkçe kökenli olan "ev" sözcügü günümüzde Türkçenin lehçe ve şivelerinde yaşamaya devam etmektedir ve göçer evli teriminde kastedilen özellikle evin çadır anlamı olmalıdır. Bu sözcüğün üzerine eklenen "+l1, +li, + lu, +lü" isimden isim yapım eki Türkçe kökenli bir ektir. Eski Türkçe devrinde "+lig, +lig, +lug, +lüg” şeklinde olan ek, "g/g sesinin düşmesi sonucu " $+1,+1 \mathrm{l}$, + lu, +lü” şeklini almıştır.

Göçer evli/evlü sözcüğü yuvarlak ünlülü şekliyle 15.-16. yüzyıldan beri varlığı takip edilebilen bir sözcüktür. Göçer evli/evlü terimiyle ilgili yapılan incelemeler sonucu görülmüştür ki sözcük, hem Türkçe kökenlidir hem de anlamsal olarak yaylaklar ve kışlaklar arasında göç faaliyetlerini sürdüren, hayvanlarına göre yaşam şartlarını şekillendiren ve göçüp konacakları yerleri önceden belirleyen Yörük/Türkmen gruba ait olan göçü anlatmak için kullanılmaktadır. Fakat sözcüğün son yıllarda Türk tipi göç faaliyetlerini anlatırken kullanılan aktif sözcüklerden birisi olduğu söylenemez.

\section{Göçer oba}

Göçer oba sözcügü günümüzde çok fazla tercih edilmeyen sözcüklerden biridir. Tarama Sözlüğünde; "göçer oba: Göçebe halk, aşiret" (Tarama Sözlüğü, III, 2009: 1718) anlamlarıyla kendisine yer bulmuştur. Sözcüğün yazıll eserlerde tespit edilebildiği ilk yer Peygamberimiz Hz. Muhammed'in amcası Hz. Hamza'nın savaşta gösterdiği kahramanlıkları anlatan ve 14.-15. yüzyıllarda Hamzavî olarak bilinen müellif tarafindan yazıya geçirilen Hamzanâme isimli eserdir. Eserde bu sözcük, "Yedi bin göçer oba idi cümle müslüman olup...” (Tarama Sözlüğü, III, 2009: 1718) şeklinde görülmektedir. Göçer oba sözcüğüne benzer bir kullanım da "göç oba”dır. Özellikle "göç oba" sözcüğü, bu kavramlara anlamsal açıdan bakan araştırmacılar tarafindan "göçebe" sözcüğünün etimolojisi verilirken tercih edilmektedir. Fakat bu durum Türk dilinin gramer yapısına uymamaktadır. Hele hele böyle bir sözcüğün literatürlere hiç girmemiş olması "göç oba" sözcüğü hakkındaki soru işaretlerini artırmaktadır. Köç- (Göç-) fiilinin "oba" sözcügü ile birleşmiş olabileceği düşünülüyor ise "göçebe" sözcüğü üzerinde dururken de dile getirdiğimiz gibi "köç- (göç-)" fiiline eklenen bir "+Ar" geniş zaman sıfat fiil ekinin olması 
gramer kuralları açısından zaruridir. Sözcük, gramer kurallarına uygun olarak "köç-er oba > göç-er oba" biçiminde ortaya çıkmış olabilir. Bu ihtimal güçlü bir ihtimal gibi görünmektedir. Yok eğer buradaki isim olan "köç (göç)" sözcüğü ise yine "göçebe" sözcüğü üzerinde dururken açıkladığımız gibi mutlaka sözcük "göç oba-sl" biçiminde "oba" ismine eklenen 3. teklik şahıs iyelik eki "-s1, -si, -su, -sü” ile birlikte birleşik sözcük hüviyeti kazanmış olmalıdır. Bu da bir ihtimal olarak düşünülebilir. Lakin ister isim olsun ister fiil olsun "köç (göç)" sözcüğünün eksiz bir şekilde "oba" sözcüğü ile birleştirilmesi dil kurallarına uygun değildir. Zaten yazılı eserlerde de sıfat tamlamaları haricinde bu şekilde vuku bulan bir kullanım tespit edilememiştir.

Eski Türkçede kendisine yer bulan ve bu günlere kadar ulaşan "oba" sözcüğü, Eski Türkçede de bugünkü anlamıyla; "oba: kabile, aşiret, boy" (Bayat ve Aliyeva, 2008: 163) biçiminde geçmektedir. Verilen tanımlar ışı ğında anlamsal olarak bakıldığında "oba" kelimesinin ilk anlamı, Orta Türkçe dönemi tarihi lehçelerinden Oğuzcada, "çadırlarda yaşayan göçebe ailelerin meydana getirdiği topluluk, oymak, çadır halkı, göçer evli kabile anlamına gelmektedir. İkinci anlamı ise, göçebe ailelerin konakladığı yer, yurt demektir. Ayrıca bölmeli göçer çadırına da oba adı verilmektedir” (Ayverdi, 2011: 943; Baykal, 1981: 74; Yediyıldız, 2018: 184). Pakalın da obayı şöyle tanımlamıştır: "Ev biçimi, birkaç direkli, uzun bölüntülü keçeden çadıra verilen addır." "Bir çadır halkına veya birkaç çadırdan ibaret olan topluluğa da oba denir" (Pakalın, 1971: II/711; Yediylldız, 2018: 184).

Göçer oba sözcüğü etimolojik açıdan bünyesindeki iki sözcükten de görüleceği üzere Türkçe kökenli bir sözcüktür. Sözcüğe anlamsal açıdan bakıldığ1 zaman çok kaynakta yer almasa da Türk tipi göç faaliyetleri için kullanıldığ1 görülür. Fakat hem geçmişte hem de günümüzde "göçer oba" sözcüğü çok tercih edilen bir sözcük değildir. $\mathrm{Bu}$ sözcükle aynı düzlemde olduğu varsayılan "göç oba" sözcüğü ise hâlihazırda dil kurallarına aykırı bir kullanım örneğidir. Bu sözcüğün sıfat ve sayılarla birlikte (Örnek: güzel oba, kara oba, iki oba, aşağı oba vb.) kullanıldığı gibi ad kökenli olan "köç (göç)" sözcüğü ile bünyesine ek almadan kullanılması dil kuralları açısından mümkün değildir.

\section{Göçgün(cü)/Göçkün(cü)}

Göçgün, göçkün, göçgüncü ve göçküncü sözcükleri Eski Türkçe ve Orta Türkçe dönemi eserlerinde yer almamaktadır. Dolayısıyla Karahanlı dönemi eserlerinden Türkçenin en önemli eserlerinden biri olan Dîvânu Lügâti'tTürk'te de mevcut değildir. Bu sözcükler, 14.-15. yüzyıldan itibaren yazılı eserlerde kendilerine yer edinmeye başlamıştır. Özellikle Anadolu sahasında yazılan Selçuklu ve Osmanlı dönemi eserleriyle birlikte bu sözcükler de 
arşivlere girmeye başlamıştır. Sözcüklere sırasıyla bakılacak olursa öncelikle göçgün sözcüğü üzerinde duralım. Göçün sözcüğü, Tarama Sözlüğünde; "göçgün: Göçebe" (Tarama Sözlüğü, III, 2009: 1719) manasıyla yer almaktadır. Göçgün sözcügünün eldeki verilerden hareketle görüldüğü ilk yazılı eser İran, Kirman ve Anadolu Selçukluları'yla ilgili İbn-i Bîbî tarafından Farsça yazılmış olan "El-Evâmirü'l-'Ala'iyye fi'l-Umûri'l-'Alâ'iyye" adlı eserin 1436 yılında Yazıcızâde (Yazıcıoğlu) Ali tarafindan II. Murat'a sunulmak üzere çevirisi yapılan Tarih-i Âl-i Selçuk Tercümesi'dir. Bu eser tam bir çeviri değildir. Müellif tarafından eser birçok yerine eklemeler yapılarak yarı tercüme yarı telif hâle getirilmiştir. Sözcük, bu eserin iki yerinde "Ebulca Han sahra-nişin ve göçgün idi yani, yaban yurtlu ve Yürük idi (Bakır, 2008: 9; Uslu, 2019: 117). Ve onun yaylagl Urtak ve Kertay taglarında idi ki azim ulu ve yüce taglardır." (Bakır, 2008: 9) ve "Alemdeki her iklimde yerlü ve sahra-nişin ve göçü̈n olurlar. Hususa o vilayetteki mera ve çayırlar ve ot çok ola... " (Bakır, 2008: 2) şeklinde geçmektedir. Burada adı geçen Ebulca Han, Türk mitolojisinde “Abulca Han, Amulca Han, Ebülce Han, Bulca Han, Olca Han” gibi adlarla da anılan ve Nuh Peygamber'in soyundan geldiğine inanılan Yafes'tir. Yazıcızâde tarafından bu eserin başına önemli eklemeler yapılmıştır. Bu dönemde oluşan milli şuur, Türk diliyle eserler verme gayreti ve tarihe verilen önemle birlikte birçok Arapça ve Farsça eser Türkçeye çevrilirken yine edebi eserlerde millileşme anlamında önemli adımlar atılmıştır. Yazıcızâde'nin Tarih-i Âl-i Selçuk Tercümesi'nin böyle bir dönemde kaleme alınmış olması esere ayrı bir değer de yüklemektedir. Göçgün sözcüğü bu anlamda çok önemlidir. Eserde Ebulca Han anlatıllrken "yerli", "sahra-nişin" ve "göçgün" sözcükleri aynı cümlede kullanılmıştır. Yerli olarak kastedilen göç faaliyetinde bulunmayan kimseler iken sahra-nişin olarak kastedilenler ise çölde hayat geçiren bedevi halk değil yaban yurtlu olarak kastedilen yani kırda, ovada yaşayan Türk halkıdır. Burada geçen "sahra-nişin" terimi sadece çölü değil, kır ve ovayı da kasteden bir sözcüktür. Aynı cümlede göçgün olarak bahsedilenlerin ise yurttan yurda göç faaliyetleri içinde bulunan Yörük/Türkmen grup olduğu anlaşılmaktadır. Zaten cümlenin devamında ve diğer cümlede göçü̈nlerin "Yürük/Yörük" olduklarından, yaylaklarının isimlerinden ve otlakların çokluğundan bahsedilmektedir. Burada geçen Yürük/Yörük terimi bu sözcügün tespit edildiği ilk kaynaktır. Yörük/Türkmen halk1 için 14.-15. yüzyıllarda "göçebe, konargöçer, göçerkonar, göçer, göçer oba, göç oba" gibi kavramların kullanılmaması ve bunların yerine "göçgün" sözcügünün kullanılmış olması dikkate alınması gereken bir durumdur. $\mathrm{Bu}$ durumdan bu yüzyıllarda Yörük/Türkmen grup için "göçgün” sözcüğünün daha çok tercih edildiği anlaşılmaktadır. Göçgün sözcügü günümüzde çoğunlukla yöresel ağız sözcüklerinden birisi olarak Anadolu halkları arasında kullanılmaktadır. Derleme Sözlüğüne de giren sözcük, Derleme Sözlüğü’nde; “göçgün: Çadır hayatı yaşayan, göçebe (Bozdoğan/Aydın, Çorum, Bor/Niğde, Milas/Muğla) (Derleme Sözlüğü, III, 2009: 2121)" anlamındayken, Ordu ili ve yöresi 
ağızlarında da "göçgün: göç eden, göçebe" (Küçük ve Ateş, 2017: 244) anlamıyla Türkiye Türkçesi ağızlarındaki serüvenini devam ettirmektedir. Bu durum sözcüğün Anadolu Yörük/Türkmen grup tarafindan yaşatılmaya devam edildiği anlamına gelir.

Göçgün sözcüğüne etimolojik açıdan bakıldığında, Türkçe kökenli "köç(göç-)" fiiline yine Türkçe kökenli bir ek olan ve aşırılık anlamında sıfat gibi kullanılan isimler türeten "+gın, +gin, +gun, +gün" fiilden isim yapım ekinin eklenmesi sonucu oluşmuştur. Standart dilde ekin "az-gın, dal-gın, bil-gin, olgun, yor-gun, üz-gün, boz-gun" gibi örnekleri de vardır. Lakin günümüz standart Türkiye Türkçesi gramer kuralları açısından "göç-" fiilinden sonra "+kın, +kin, +kun, +kün" ekinin gelmesi gerekir. Bu vesileyle "göçgün" sözcüğü, Türkiye Türkçesi ağızlarında varlığını devam ettirirken standart Türkiye Türkçesinde yerini “göçkün”e bırakmıştır.

Göçgüncü sözcüğü de göçü̈n sözcüğünden üretilmiştir. Bu sözcük de Eski ve Orta Türkçe dönemi eserlerinde kendisine yer bulamamıştır. Anlamsal açıdan bakıldığında göçgüncü sözcüğü, Tarama Sözlüğünde; "göçgüncü: Göçer, göçebe" (Tarama Sözlüğü, III, 2009: 1719) anlamında kendisine yer bulmuştur. Sözcük elde edilen verilerden hareketle 14.-15. yüzyıllardan itibaren yazılı dilde görülmeye başlanmıştır. Özellikle Erzurumlu Mustafa Darir bin Yusuf'un 1388 yılında Mısır Hükümdarı Berkuk adına Eb-ül Hasan-ül Bekrî ile Abdülmelik bin Hişam tarafindan yazılmış olan Siyer kitaplarından Türkçeye çevirdiği "Siyer-i Nebevî" adlı eserde, "göçgüncü” sözcüğü çok geçer. Bu eserin ilgili yerlerinde sözcük, "Göçgüncü Araplarından bir bölük Araplar çekişip gavga birle..” ve "Ol Sürûd ilinde göçgüncü Araplar olurdu." (Tarama Sözlüğü, III, 2009: 1719) biçimlerinde Araplar ile birlikte geçmektedir. Sözcük yine Arap tarihçilerinden Mehmed bin Ömer Vâkıdî’nin Suriye'nin Müslümanlar tarafından fethini anlatan "Fütuh-üş-Şam" adlı eserinin Erzurumlu Mustafa Darir bin Yusuf tarafından "Fütuh-üş-Şam Tercümesi" adıyla 13881392 yılları arasında yapılan tercümesinde de geçmektedir. Sözcük, bu eserde, “Amma göçgüncü Araptan otuz bin er vardır." (Tarama Sözlüğü, III, 2009: 1719) şeklinde yine Araplarla birlikte kullanılmıştır. Sözcük, Hünkar Hacı Bektaş-1 Veli'nin söylencelerine dayanan ve 15.-16. yüzyıllarda yazıya aktarılan "Velâyetname-i Hacı Bektaş" adlı eserde, "Padişah ona hışm edip gazaba geldi ve söyledi ki: O göçginci Tatar Kavmi kimdir ki benim üzerime gele dedi ." (Malçok Meteer, 2012: 93) biçiminde geçer. Burada kastedilen Tatar kavmi, yaylak ve kışlaklar arasında göçen bir kavimdir. Göçgüncü sözcüğü yine 15. asır tarihçilerinden Oruç Bey'in bir münasebetle Oğuzlardan bahsederken, " $\mathrm{Bu}$ Oğuz taifesi göçgüncü Yürükler idi.” (Güler, 2015: 2) biçimindeki cümlesinde de geçer. Bu örnek metinlerden de tespit edildiği üzere göçgüncü sözcüğünün Yörük/Türkmen grupla birlikte çok kez kullanıldığg görülmektedir. 
Göçü̈nü sözcüğü de etimolojik olarak hem kelimenin kökeni hem de aldığ 1 ekler itibariyle Türkçedir. Sözcük, Türkçe kökenli "köç- (göç-)" fiiline yine Türkçe kökenli bir ek olan ve aşırılık anlamında sıfat gibi kullanılan isimler türeten "+gın, +gin, +gun, +gün" fiilden isim yapım ekinin ve onun üzerine de yine Türkçe kökenli olan ve meslek adları yapan “ $+\mathrm{c} 1,+\mathrm{ci},+\mathrm{cu},+$ cü” isimden isim yapım ekinin eklenmesi sonucu oluşmuştur. Standart dilde "soy-gun-cu, boz-gun-cu” gibi örnekleri de vardır.

Göçkün sözcüğü, yukarıda bahsedilen “göçgün” ve "göçgüncü” sözcükleri ile hem kavramsal açıdan, hem anlamsal açıdan hem de etimolojik açıdan aynı düzlemde yer almaktadır. "Göçgün" ve "göçgüncü" sözcükleri ile arasındaki fark " $\mathrm{g} \sim \mathrm{k}$ " ses değişimidir. Bu değişim sonucu aşırılık anlamı taşıyan isimler yapan "+gın, +gin, +gun, +gün, +kın, +kin, +kun, +kün" fiilden isim yapım eki 8 şekilli olarak varlığını devam ettirmektedir. Günümüz standart Türkiye Türkçesinde bu eklerin alımında özellikle "f, s, t, k, ç, ş, h, p" sesleriyle biten fiiller "+kın, +kin, +kun, +kün" eklerini alırken, diğer seslerden sonra "+gın, +gin, +gun, +gün" eklerinin geldiği görülür. Lakin 15. yüzyılda bu ayrım net olarak oluşmadığı için "köç- (göç-)" fiilinin hem "+gün” hem de "+kün” yapım ekini alması sonucu "göçgün, göçgüncü, göçkün, göçküncü” sözcükleri oluşmuştur. Göçkün sözcüğü, bu sebeple ayrı bir sözcük olarak düşünülmemelidir. Standart Türkiye Türkçesinde ekin "bit-kin, geç-kin, seç-kin, tut-kun, küs-kün” gibi örnekleri mevcuttur. Göçkün sözcüğü de standart Türkiye Türkçesinde yer alır ve standart Türkiye Türkçesine halk ağzından girmiş bir sözcüktür. Göçkün, Türkçe Sözlükte; "göçkün: 1. Göçecek duruma gelmiş; 2. Göçebe; 3. Yaşı ilerlemiş (kimse), çok yaşlı (kimse).” (Türkçe Sözlük, 2011: 955) olarak geçer. Göçkün benzer açıklamalarıyla Köken Bilgisi Sözlüğü (Gülensoy, 2011: 375)'nde de yer alır. Sözcük, halk ağzından derlemeler yapılarak oluşturulan Derleme Sözlüğü'nde; “göçkün: 1. Çadır hayatı yaşayan, göçebe (Yeşilova/Burdur, Tavas/Denizli, İskilip/Çorum, Ordu, Bor/Niğde); 2. Yaşı ilerlemiş kimse (Mudanya/Bursa)" (Derleme Sözlüğü, III, 2009: 2121) şekliyle hem çadır hayatı yaşayan Yörük/Türkmen grup için hem de yaşı ilerlemiş olan yaşlı insanları anlatmak için kullanılmaktadır. Sözcükle ilgili Tarama Sözlüğü’nde ise; "göçkün: Taşınır eşya" (Tarama Sözlüğü, III, 2009: 1720) açıklaması yapılır. Buradan aynı kökten gelen "göçgün" ve "göçkün" sözcüklerinin taşınır eşya, yük anlamında da kullanıldığı sonucuna varılmaktadır. Tarama Sözlüğü’nden tespit edildiği üzere sözcük, Osmanlı saltanatının kuruluşundan II. Bayezid çağının yarısına kadar olan dönemi anlatan ve adı Aşık Paşazade Tarihi olarak da bilinen Tevârih-i Âl-i Osman'da; "Bizim göçkünimizi yaylaya gittiğimiz vakıt sizde emanet koyalım." (Tarama Sözlüğü, III, 2009: 1720) şeklinde yer almaktadır. Derviş Ahmet Âşıkî bin Yahya tarafindan yer yer manzumelerle süslenerek meydana getirilen bu eser, Osmanlı tarihi açısından büyük bir kıymete sahiptir. Bu eserde "göçkün" sözcüğünün kendisine yer bulması, sözcüğün Anadolu halkı tarafindan o 
yüzyıllarda kullanıldığı anlamına gelir. Burada gözden kaçırılmaması gereken önemli nokta "taşınır mal" olarak gösterilen göçkünün, yaylaya göç eden Yörük/Türkmen gruba ait yük eşyası ile olan ilişkisidir. Yörük/Türkmen grubun taşınır eşyasından hareketle göçkün sözcüğünü Yörük/Türkmen grupla da ilişkilendirmek doğru bir değerlendirme olacaktır.

Göçkün sözcüğüne Batılı araştırmacıların verdiği anlamlar incelendiğinde Radloff (1899: II-1291) sözcüğün anlamını 'göçebe' olarak verirken; Sevortyan (1980: 91) sözcügün anlamlarını "1. Toprak kayması, çı̆g, göçme, çökme; 2. Göçebe, göçer” olarak verir. Sevortyan ve Radloff görüldüğü üzere sözcüğe göçebe anlamı vermişlerdir. Batılı araştırmacılar tarafından genel olarak karşılık vermede göçebe terimini kullanılmıştır.

Göçküncü sözcüğü, yukarıda bahsedilen “göçgüncü” sözcüğü ile hem kavramsal açıdan, hem anlamsal açıdan hem de etimolojik açıdan aynı düzlemde yer almaktadır. "Göçgüncü” sözcüğü ile arasındaki fark "g k" ses değişimidir. Sözcügü̈n literatürde "göçkinci" şekli de mevcuttur. Tarama Sözlügü’nde; "göçküncü: Göçer, Göçebe” (Tarama Sözlüğü, III, 2009: 1719) anlamlarıyla yer alan sözcük, aynı kökten gelen "göçgün, göçgüncü, göçgün" sözcükleri gibi 15. yüzyıldan itibaren Türk yazı dilinde görülmeye başlamıştır. Göçküncü sözcüğünün ilk tespit edildiği eserlerden birisi, Hünkar Hacı Bektaş-1 Veli'nin söylencelerine dayanan ve 15.-16. yüzyıllarda yazıya aktarılan 'Velâyetname-i Hacı Bektaş' adlı eserdir ve sözcük bu eserde "Tatarlar olarak geçen Moğol hakanı Gülü Han'ın Müslüman olduktan sonra Sultan Alaeddin'den yer istemesini konu alır” (Duran, 2007: 505). Göçküncü sözcüğü bu eserde; "İmdi ilçim huzurına varıcak mektubum saña vasil olıcak gerekdür ki leşkerüme kifayet idecek mikdarı Diyar-ı Rum'da yazla ve kışla vire ki zira bizler göçkinci kavmüz kış ve yaz bir yerde karar idüp turamazuz. Varalum ol gösterdüginüz yerlerde yürüyelüm ve saña dahı arka ve yardım olalum ve dostuña dost düşmanına düşman olalum ve işitdük Diyar-ı 'Acem senüñ elinde imiş. Bag்dād Vilayeti'nden gayrı uş anı dahı ben aldum. Kendi memleketüñdür.” (Malçok Meteer, 2012: 103) şeklinde geçmektedir. Burada Gülü Han'ın talebini alan Sultan Alaeddin ulular ve beylerle görüşür ve bu görüşme Velâyetname'de şu şekilde anlatılır: "Sultan 'Ala'addįn dahı uluların ve biglerin katına cem' idüp anlar ile meşveret kılup "Ulular ve bigler siz ne dirsiz ve nice idelüm? Anlara klşla ve yazla gerekdür ki fi'l-vaki` anlar Tatar Kavmidür. Konup göçmege ögrenmişlerdür. Yaz ve kış bir yerde karar idemezler. Bunlar içün ne tedbir dersiñüz ve ne tedarik idersiz?" didi. Aytdllar: "Hükm padişahımuzuñdur. Siz her ne ki ra'y u tedbir derseñüz ve mübarek hātır-l şerifiñüz her nice ki dilerse öyle emr eyler ki fi'l-hakika bu yerde din düşmanları ziya ġalibdür. Çünki anlar Müslüman oldllar. Ne kadar ise anlaruñ ziyanı yokdur. Bizlere arka ve yardım olurlar. Sivas'uñ ve Kayseriyye'nüñ ulu taġları, yaylakları olsun ve ol etrafda klşla yapup kış olıcak anda kışlasunlar ve 
yazın çılkup zikr olunan taġlarda otursunlar... Gülü Han'a sundı. Açup okudılar ve mefhumuñ bildiler ve dahı Erzincan'dan göçüp Rum'a geldiler. Sivas'dan Kayseriyye'ye varınca Çorum'dan Ankara'ya ve Maliye kurbuna varınca ol yerleri Tatara üleşdürdiler. Gülü Han dahı 'asker ile konup oturdılar ve kışlalar ve köyler ve kendler eyleyüp yurt ve yuva bağlayup karar itdiler. Yaz ve bahar oldukda göçdiler. Zikr olunan taġlarda yaylaklarda ve güzin ve klş vaktlarında inüp kışlalarında kışladılar." (Malçok Meteer, 2012: 104-105). Bu cümlelerden anlaşıldığına göre Sultan Alaeddin konup göçmeyi öğrenen Müslüman Moğollara Sivas ve Kayseri dağlarını yayla, Malya Ovası'nı da güzle/kışla olarak vermiştir. Bu metinlerde göçküncü sözcüğü ile birlikte kullanılan yaylak ve kışlak terimleri Yörük/Türkmen grup için de önemlidir. Yörük/Türkmen grup yazın yüksek dağlara giderken kışın daha sıcak ovalara inmektedirler. $\mathrm{Bu}$ metinlerde de görüldüğ̈̈ üzere Anadolu'da yaşayan Moğollar, yaylamak ve kışlamak için yer talep etmişlerdir. Bu durum göçküncü sözcügünün o yüzyıllarda yaylacılık faaliyetleri için kullanıldığı anlamına gelir. Burada geçen "bizler göçküncü kavmiz kış ve yaz aylarında ayn yerde kalamayzz" sözünden yine Anadolu'ya gelen Moğolların göç faaliyetlerinin Türk tipi göç faaliyetlerine benzediği anlaşılmaktadır. Fakat bu benzerlik birbirine karıştırılmamalıdır. Kafesoğlu (Kafesoğlu, 2005: 215)'nun söylediği gibi her topluluk gibi bozkırlarda yasamış çeşitli kavimlerin de, ekonomik özellik yanında, ayrı ayrı sosyal, dini, idari ve siyasi cepheleri bulunacağ 1 hesaba katılmadıkça, mesela Türk'ü Moğol'dan ve bazı Hind-Avrupalı kitleleri birbirinden ayırmadıkça, onların "bozkırlı", "göçebe" ve "köylü" vasıflarının tayin ve izahında kesin ve doğru bir sonuca varmanın hemen hemen imkânsız olduğu göz önünde bulundurulmalıdır.

Göçkün ve göçküncü sözcükleri, etimolojik olarak göçgün ve göçgüncü sözcükleri ile aynı kökten gelen Türkçe sözcüklerdir. Sözcüklerin aldığı ekler de Türkçedir. Yukarıda detaylı izahı yapıldığı için ayrıca etimolojik değerlendirme yapılmayacaktır.

Göçgün, göçkün, göçgüncü ve göçküncü sözcüklerinin öncelikle tarihi Türk lehçelerindeki seyrine bakıldığında sözcüğün tespit edildiği tek tarihi lehçe Çağatay Türkçesidir. Sözcük, Çağatay Türkçesinde; "köçkün: Göçmen kuşu" (Ünlü, 2013: 653) anlamıyla tespit edilmiştir. Sözcük, Ebulgazi Bahadır Han'ın 1659 yılında tamamladığ 1 eseri Secere-i Terakime'den hareketle Çağatay Türkçesine mal edilen sözcüklerdendir. İlgili sözcüklerin çağdaş Türk lehçelerindeki izlerine bakıldığında sözcüklerin bazı çağdaş Türk lehçelerinde işlek şekilde yaşamlarını sürdürdüğü görülür. Öncelikle Altay Türkçesine bakıldığında sözcük, Altay Türkçesinde; "köçkin: 1. Göçebe, 2. Yerinde duramayan” (Gürsoy-Naskali ve Duranl1, 1999: 119) biçimindedir. Karaçay Malkar Türkçesinde sözcük; “köçkünçü: Göçmen, muhacir” (Tavkul, 2000: 273) şeklinde varlığını devam ettirmektedir. Sözcük, Tatar Türkçesinde; 
"küçkinçiler: Konargöçer” (Gülersoy, 2011: 538) biçiminde kullanılırken Başkurt Türkçesinde de; "küskinsiler: Konargöçer” (Gülersoy, 2011: 538) biçiminde kullanılmaya devam edilmektedir. Bu örneklerden hareketle göçgün, göçkün, göçgüncü ve göçküncü sözcüklerinin Türk tipi göç faaliyetleri için kullanılan canlı sözcüklerden olduğunu söylemek yanlış olmayacaktır.

\section{Göçmen/Göçmel}

Göçmen sözcüğü, standart Türkiye Türkçesinde; "göçmen: Kendi ülkesinden ayrılarak yerleşmek için başka ülkeye giden (kimse, aile veya topluluk), muhacir: Ama biz de yeni göçmeniz, halden anlarız. (N. Araz); 2. Sicak iklimli ülkelere giden (hayvan)" (Türkçe Sözlük, 2011: 95) anlamıyla bilinse de geçmişte Türk tipi göç faaliyetlerini anlatmak için kullanılan sözcüklerden biri olarak kullanılmıştır. Sözcüğün göçmen biçiminde ilk tespit edildiği yer Şeyh Süleyman Efendi'nin Lügât-i Çağatay ve Türk-i Osmani'sidir. İstanbul'da yazılan bu eser tarihi Türk lehçelerinden Çağatay Türkçesine ait bir sözlük çalışmasıdır. Sözcük, bu eserde, "göçmen: konar gö̧̧er bedevi mesellü olan halk, göçmen ulus. Kabayil-i Türkmaniyye gerd, Kırgız, Kazak, Kipçak içinde caridir. Mezeng ve Çevgi ve Çingeni dahi bu gibidir.” (Durgut, 1995: 550) biçiminde geçer. Burada sözcüğün konargöçer olarak karşıllk bulması anlamsal açıdan önemlidir. Her ne kadar Türklerden örnek vermek yerine konargöçer Bedevi gibi olan şeklinde örnek verilmiş olsa da hem göçmen sözcüğünün anlamı hem de konargöçer sözcügünün kullanılması açısından Şeyh Süleyman Efendi'nin sözlüğü önemli bir kaynaktır. Kırgız, Kazak, Kıpçak Türkleri ile Çingenelerin ve Bedevi Arapların hepsinin yaptığı göç faaliyetleri göçmen sözcügü ile karşılık bulmuştur. Bu durum, Çağatay Türkçesinde Çingeneler, Türkler ve Arapların her ne kadar göç faaliyetleri farklı olsa da yapmış oldukları göç hareketliliğinin aynı sözcükle adlandırıldığını gösterebilir. Fakat bunu net olarak söyleyebilmek için daha fazla araştırma yapılmalıdır. Sözcük, Çağatay Türkçesi eserlerinin taranması sonucu oluşturulan Çağatay Türkçesi Sözlüğü’nde; "köçmen: 1. Her zaman göçer olan, bedevi; 2. Şehir adı, konmas" (Ünlü, 2013: 653) olarak iki farklı anlamda yer almaktadır. Şehir adı olarak Ebul Gazi Bahadır Han'ın Şecere-i Terâkime adlı eserinden tespit edilmiştir. Göçmen sözcüğü diğer Çağatay dönemi eserlerinde mevcut değildir.

Göçmen sözcügü günümüzdeki anlamıyla Cumhuriyet dönemi dil devrimi ile yaygın kullanım alanına ulaşmış bir sözcüktür. Sözcügün eski ş̧ekli günümüzdeki anlamıyla kullanılmamış olsa da göçmel sözcüğü olmalıdır. Göçmel sözcüğünde yer alan "+mAl” yapım eki Türkçede pek işlek olmayan bir ektir. Ekle ilgili Zeynep Korkmaz, "Türkiye Türkçesinde yalnız sağmal (sağılan, süt veren, sütlü) sözünde görülen ve sıfat türeten bir ektir: sağmal inek, sağmal hayvan gibi. Tek örnek olduğu için ekin işlevini kesin olarak belirlemek mümkün olamıyor. Ancak eldeki örneklere göre, fiildeki oluş ve kılışa sahip 
olma niteliğini veren bir sıfat eki olduğu söylenebilir." (Korkmaz, 2007: 96-97) tanımını yapsa da ekin Türkiye Türkçesinde tek örneğinin olmadığı ortadadır. Özellikle halk ağzında kullanım alanını devam ettiren göçmel, bitmel, eğmel, çöğmel, çöymel sözcüklerini de dikkate almak gerekir. Ferdi Güzel (2018), tarafından Türkiye Türkçesi ağızlarında ekin 3 isimden isim yapım eki örneği, 11 fiilden isim yapım eki örneği olmak üzere 14 örneği tespit edilmiştir. Fakat özellikle ekin isme gelen şekillerine detaylı bakmak gerekir. Göçmel sözcüğüyle ilgili Türkiye Türkçesi ağızlarına ayrıntılı bakılırsa sözcüğün Çankırı ve Ankara ağızlarında kullanıldığı görülür. Sözcük, bu ağızlarda; "göçmel: Herhangi bir yere sonradan gelen (kimse)" (Derleme Sözlüğü, III, 2009: 2121) anlamındadır.

Standart Türkiye Türkçesinde ve Türkiye Türkçesi ağızlarında görülen“+mAl” yapım ekinin Doğu Türkçesinde kiriş-mel "zorlayan, parazit”, tanı-mal "tanınan, ünlü", tüş(i)-mel "bakan, vekil"; Kazak Türkçesinde poşamal "korku, saygı" gibi örnekleri de vardır (Korkmaz, 2007: 97). Räsänen (Ost. Gr., 127) Brockelmann'a dayanarak ekin yapısını “+mA+1 > mAl” olarak vermiştir. Räsänen'in bu tespiti detaylı araştırmaya muhtaçtır.

Göçmel ve göçmen sözcükleriyle alakalı Orhan Şaik Gökyay da önemli bir değerlendirme yapmış ve bu değerlendirmede; "Bugün de Türkçede göçer evli, göçeri, göçebe, göçmel ve göçmen sözcükleri hep bir kökten, "göç-" kökünden türemiştir ve aşağı yukarı bir anlamda kullanılmaktadır. Biz göçmen ve göçmel sözcüklerini iki ayrı anlamda kullanabiliriz diyorum. Nitekim İngilizcede emigrate ve migrate sözcükleri bir kökten gelmekle birlikte iki ayrı anlamı vermektedir. Emigrate başka bir yerde sürekli olarak yerleşmek üzere kendi yurdunu bırakan kimse, demektir. Bunun Türkçe karşıllı̆̆ için biz de 'göçmen'i kullanıyoruz. Migrate ise bir yerden başka bir yere geçici olarak göçen, bir yerden başka bir memlekete, kasabaya, koleje, üniversiteye ve başka bir yere kalkan demektir. Kuşlar ve balıklar için ise yaşadıkları yerden başka bir yere, mevsimlere uyarak şaşmadan gidip gelen demektir ki bunlar için de 'göçmel' diyebiliriz” (Gökyay, 1981: 30-31) şeklinde göçmel ve göçmen sözcükleriyle alakalı görüşünü ortaya koymuştur. Buradan hareketle mevsimsel döngülere göre göç faaliyetlerini sürdüren kuşlar için göçmel teriminin kullanılması mantıksal düzlemde uygun görünürken, dil pratikleri açısından terimsel karmaşalar yaratabileceği kaygısı da göz önünde bulundurulursa zor gibi durmaktadır.

Göçmel ve göçmen sözcüklerinin Tarama Sözlüğündeki durumuna göz gezdirildiğinde, göçmen sözcüğü Tarama Sözlüğünde mevcut değildir. Göçmel sözcüğü ise Tarama Sözlüğünde, "göçmel: Göçülecek, nakle elverişli" (Tarama Sözlüğü, III, 2009: 1723) anlamıyla verilmiştir ve bu anlamına tanık olarak gösterilen metin Yazıcızâde Ali'nin Tevârih-i Âl-i Selçuk'undandır. Sözcük, 
burada, "Bayçu Noyin çokluk çeriler ve havaşi ve havatin ve oğul kuzla gö̧̧mel bu diyar kasdına gelür" (Tarama Sözlüğ̈̈, III, 2009: 1723) şeklindedir. Metne detaylı bakılırsa sözcüğün anlamının "göçülecek, nakle elverişli" olması zor ihtimaldir. Sözcük burada önceki anlamlarına benzer bir anlamda kullanılmış olmalıdır. Cümleye ayrıntılı incelendiğinde "göçerek" anlamı verdiğ̈i anlaşılmaktadır. Bugün Türkiye Türkçesi ağızlarında sözcüğün "Herhangi bir yere sonradan gelen (kimse)" anlamının olduğu düşünülürse buradaki anlamı da buna yakın bir anlam olmalıdır. Burada da kastedilen Boyçu Noyan'ın tüm ailesiyle göçerek o diyara gitmiş olmasıdır. Sözcüğün Tarama Sözlüğündeki anlamının güncellenmesi anlam tutarlılığı açısından önem arz etmektedir.

Göçmel sözcüğünün ilk tespit edildiği yer, 15. yüzy1l Osmanlı tarih yazıcılığının timsal eseri Tevârih-i Âl-i Osman'da Oruç Beg Tarihi içinde Süleyman Şah ve onun cemaati ile ilişkilendirilerek; "Süleymân şâh dahı Acem memleketinden ve Erzırûm vilâyetinden kopup Erzincan'a geldi. Erzincan'dan Rûm vilâyetine girdiler. Amâsiyye tarafi kim Rûmîlerdür, ol tarafdan çok gazâlar itdiler. Rûm vilâyetinden hayli yirler aldılar. Âkıbet andan göçüp Haleb'e çıkdılar. Ca 'ber kal 'ası dirler, bir kal 'a vardur, gelüp öñüne kondılar. Firat ırmagl suyı öñlerine geldi, Furat ırmagl suyın geçmek istediler. Yol iz bilmez göçmel Yörükler idi. Gāfilin Firat ırmagına ugradılar. Süleymân şâh at depdi Fırat'a girdi." ve "Âl-i Selçük neslinden Sultân Alâeddin dahı Acem vilâyetinden kopup, Rûm vilâyetine gelüp teveccüh idüp, Yunan vilâyetin, kim şimdi Karaman vilâyetidür, ol vilâyetleri dutup pâdişâh olmuşidi. Sivas şehrini ve Konya'yı binâ idüp yapdı. Ve dahı Acem vilâyeti Cingiz Han'dan kim karış muruş olup âlem bir dürlü olmışidi. Oguz tâyifesi kim vardur i timâdlular idi, göçmel Yörükler idi." (İğci, 2011: 2-3) ş̧ekillerinde Oğuz Türklerinin mevsimlere göre olan göç döngülerini anlatırken kullanılmıştır. Burada sözcüğün Yörük/Türkmen grupla birlikte kullanılması 15. yüzyılda kullanım alanının boyutu hakkında fikirler vermektedir.

Göçmen ve göçmel sözcüklerine etimolojik açıdan bakılacak olursa ikisi de Türkçe "köç- (göç-)" fiiline eklenen fiilden isim yapım ekleriyle oluşmuştur. Burada önemli olan 14.-15. yüzyıl yazılı metinlerinde göçmel sözcüğü yer alırken, göçmen sözcüğünün 1882 yılından sonra literatürlerde yer almaya başlamasıdır. Konuyla ilgili Sevan Nişanyan'ın tespiti önemlidir. Nişanyan, 1935 yılında yazılan Osmanlıca Cep Sözlügü̈'nde yer alan "muhacir" karşıllı̆g 1 ile verdiği göçmen sözcüğünün 14. ve 15. yüzyıllardaki şeklinin göçmel olduğunu izah etmeye çalışmıştır (Nişanyan, https://www.nisanyansozluk.com/?k=g\%C3\%B6\%C3\%A7men). $\quad \mathrm{Bu}$ durum özellikle Cumhuriyet dönemi Türkçeleştirme çalışmalarında 'bir işi yapan kimse' anlamında sözcükler türeten " $+\mathrm{mAn}$ ” fiilden isim yapım ekinin tercih edilmesiyle açıklanabilir. Cumhuriyet öncesi dönemde çok aktif olmamakla birlikte değirmen, sokman, azman, kocaman, şişman, dalaşman, duman, yaman 
gibi adların türetilmesinde görev alan " $+\mathrm{mAn}$ " fiilden isim yapım ekiyle Cumhuriyet döneminde: “çevirmen 'mütercim', eğitmen 'mürebbî, eğiten', okutman 'lektör', öğretmen 'muallim', yazman 'sekreter, kâtip', sayman 'muhasip', gezmen 'turist', eleştirmen 'tenkitçi, münekkit', danışman 'müşavir' vb. sözcükler türetilmiştir. Zeynep Korkmaz'ın da ifade ettiği gibi, "bu yeni türetmelerde ekin bilinen $-I c I$ / - UcU, -An ekleriyle görevdeş işlevi yerine batı dillerinden man 'adam, insan' anlamı hakim olduğu için, bu şekiller zaman zaman eleştiriye uğramışsa da eski türetmelerde de 'işi yapan kimse' anlamı vardır. Danışman, öğretmen, sayman gibi sözlerin tutunması da ekin yadırganmadığını gösterir" (Korkmaz, 2007: 98). Bunun sonucu olarak da "+mAl" yapım ekinin önemi azalmış ve kullanım alanı daralmıştır. "+mAl" yapım ekininin 15. yüzyıldaki kullanımıyla alakalı Nişanyan, Moğolca “ $+m A l$ ” yapım eki Türkçe “-mIş" değerindedir. Tarih-i Âl-i Selçuk’tan verdiğimiz örnek sözcügün 15. yüzyılda Moğolca olarak algılandığını düşündürür (Nişanyan, https://www.nisanyansozluk.com/?k=g\%C3\%B6\%C3\%A7men) demektedir. Evet “+mAl” yapım eki Moğolca kökenli olabilir ama standart Türkiye Türkçesinde, Türkiye Türkçesi ağızlarında ve Çağdaş Türk lehçelerinde birçok örneğinin olması ve göçmel sözcügünün çok aktif olmasa da Türk tipi göç faaliyetleri için geçmişte kullanılmış ve hâlâ kullanılıyor olması ekin Türkçeleştiğini veya Türkçe kökenli olduğunu ortaya koyan canlı örneklerdir.

Göçmel ve göçmen sözcükleriyle alakalı bu değerlendirmelerden sonra söyleyebileceğimiz eski kullanıma sahip olan göçmel sözcügüuür ve sözcük genel olarak Yörük/Türkmen grubun mevsimlere göre yaylak ve kışlak arasında yaptıkları göç faaliyetleri için kullanılmış arkaik diyebileceğimiz bir sözcüktür. Sözcügün geçtiği eser sayısı az olsa bile göçmen sözcüğü ile karşılaştırıldığ 1 zaman aktif kullanılmasa da göçmel sözcüğü Yörük/Türkmen grubun mevsimsel göç faaliyetleri için kullanılırken, göçmen sözcüğü ise standart Türkiye Türkçesinde kendi ülkesini bırakıp başka ülkeye giden muhacirler için kullanılan bir sözcüktür.

\section{Konargöçer/Göçerkonar}

Göç merkezli sözcüklerden bir diğeri konargöçer sözcügüdür. $\mathrm{Bu}$ sözcük özellikle Anadolu Yörük/Türkmen grup tarafından en çok tercih edilen sözcüklerden biridir. Bu sözcük ilk Türkçe metinlerinde görülen ve son yıllarda tercih edilirliğini artıran bir sözcüktür. Tarihi belgeler 1şı̆̆ında geçmişi takip edilebilen bu sözcüğün ilk tespit edildiği yer, Uygurlar döneminde Orhun Alfabesiyle 753 yılında dikilmiş olan Taryat (Terhin) yazıtıdır. Bu yazıtta konuşan Uygur Hakanı Bilge Moyun Çor'dur. 1970 yılında Moğolistan'ın Arhangay şehrinin Doloon Mod bölgesindeki Terhin ırmağı yakınlarında Tarbagatay Dağları'nın $2 \mathrm{~km}$ güneyinde N. Serodjav ve V.V. Volkov adlı iki arkeolog tarafından bulunan bu yazıtın batı yüzünde konargöçer sözcüğü; "tört 
bulungdakı bodun iş güç ebirür yagım bölük yok boltı ötüken eli tegresi ikin ara ılgam tarılarım Sekiz Selenge Orkun Togla Sebintürdü Kargu Burgu ol yirimin subımın konar köçer ben. \{dört taraftaki halklar (benim) işimi gücümü görürler. Düşmanım Bölük yok oldu. Ötüken ülkesi (ve) çevresi, ikisi arasında tarlalarım; Sekiz-Selenge, Orkun, Togla, Sebintürdü, Kargu (ve) Burgu yerlerimde (ve) sularımda konar göçerim\}" (Gömeç, 1995: 74) biçiminde geçer ve devamında yer alan "yaylagım ötüken kuzı kidin uçı tez başı öngdüni kanyuy künüy ... . ılgam ötüken yiri ongı tarkansüy yagı bodunkı kagangı birigerü uçı altun, yış kidin uçı kögmen ilgeru uçı [kadırkan yış] \{Yaylam Ötüken’in kuzey-batı ucu Tez-Baş1, doğusu Kanyuy (ve) Künüy (nehirleri), tarlalarım Ötüken bölgesi, kuzeyi Tarkan Süy düşman halka (ve) kagana, güney ucu Altun-Yış, batı ucu Kögmen, doğu ucu (Kadırkan .Yış)\}" (Gömeç, 1995: 74) ifadelerinden Moyun Çor’un yaylağının ve tarlalarının yeri öğrenilir. Yazıtın batı yüzündeki bu anlatımda Moyun Çor, Uygurların hem tarla işleriyle uğraştığını hem de Selenge, Tuğla, Orhun ırmakları ile bu irmakların kolları arasında konup göçtüklerini anlatır. Bu durum ilk Türklerden olan Köktürkler ve Uygurların yaşam ş̧ekillerini "konar göçerim" şeklinde bizzat itiraflarıdır. Yukarıda verdiğimiz Köktürkçe/Uygurca belgede geçen konargöçer terimiyle alakalı Saadettin Gömeç'in; “konar-göçer deyimi kültür tarihimiz için oldukça mühimdir. Bugüne kadar Türkleri hayvancılıkla uğraşan, göçebe bir kavim olarak telakki edenlere karşı; bu yazıt ve cümleler en güzel cevabı verir sanırız. $\mathrm{Bu}$ zamana kadar Türkler için yarı göçebe deyimi kullanılmıştır. Konargöçer terimi ile benzeşmekte ise de, bundan sonra eski Türkler için konargöçer terimini kullanmak daha doğru olacak kanaatindeyiz. Zaten bu belgelerden de anlaşılacağı üzere, Türkler çiftçilikle de uğraşmaktadırlar. Ekip biçtikleri tarlaları vardır." (Gömeç, 1995: 82) ifadeleri ilk Türklerin yaşam şekillerinin özellikle Avrupalı tarih yazıcıları tarafından isteyerek ya da cahillik sonucu yarı göçebe olarak adlandırılmasının doğru olmadığı sonucunu ortaya koyar. Tarım ve hayvancılık metinlerden de anlaşıldığ üzere Türk tipi göç faaliyetlerinin bir parçasıdır.

Çin'in kuzeyindeki bölgede yaşayan Türk boy ve toplulukları hakkında, Çin kaynaklarında (özellikle Hunlardan itibaren) önemli bilgiler bulunmaktadır. Hem Çin kaynaklarında hem Türk kaynaklarında hem de diğer paralel tarihi kaynaklarda yer alan bilgiler, büyük bölümü konargöçer hayat süren; yerleşik dönemlerinde Ötüken'i başkent/ana idare merkezi olarak kullanan eski Türk boy ve topluluklarının kendilerinden önce yerleşik hayata geçen ve ciddi bir tarım ve üretim toplumu olan Çinlilerle sürekli alışveriş içinde olduklarını göstermektedir (Alyılmaz, 2013: 3). Çin kaynakları ve diğer kaynaklar da ilk Türklerin hayat şekilleri içinde konup göçmenin ve tarımın önemini ortaya koymaktadır. 
Konargöçer sözcüğü daha sonraki tarihi Türk lehçelerinden Karahanlı Türkçesi, Harezm Türkçesi, Kıpçak Türkçesi ve Çağatay Türkçesi metinlerinde "konar göçer, konar göçerim" vb. şekillerinde tespit edilememiştir. 13.-15. yüzyıllar arasını kapsayan Eski Anadolu Türkçesi dönemi eserlerinde de sözcük, ilgili şekliyle mevcut değildir. Selçuklu dönemi eserlerinde de sözcük yer almamaktadır lakin Osmanlı dönemi eserlerinde yer almaktadır. Konargöçer sözcüğü, Osmanlı Devleti padişahlarından II. Selim devrine ait Merkez ve Umumi Kanunnâmede, Yörüklerle alakalı bilgiler verilirken geçmektedir. $\mathrm{Bu}$ bilgilerin verildiği metinlerde konargöçer sözcügü; "Yörük taifesi göçer halktır; mukarrer yerleri ve sancağl ve sancak beylerine ihtisablar olmayub ăgalar subaşılarıdır. Anlardan şöyle ki, gâliz günâh sadır olub siyasete müstahak olsalar kadılar hükm edüb hüccet verdükten sonra siyaseti subaşllarınındır deyü sâbıkan hükm-i şerîf verilmişdür... Yörü̈̆̈̈n bir yerde ikameti ve kararı olmayub daim hareket üzere olmağın gerdek resmine toprak sahibi tarafindan dahl olunmaz. Ve Yörük taifesinin avreti için subaşılar ve sipahiler toprağından çıktı deyü nizâ etseler, çünkü Yörük konar göçer taifedir, karyede ikametleri yoktur ki, toprağa taallukları ola ve topraktan seyyibe avretin gerdeği resmi toprak issi almak mukim ve mütemekkin reaya avretine mahsustur, Yörük avretinin gerdek resmine toprak davası olub sahib-i tımar ve subaşı tarafindan dahl olunmaz." "Yörük taifesi konub göçtükleri itibariyle kimesneye raiyyet olmayub her kangı mahalle giderlerse cemaatleri ile yazlldiklar karye sipahisine resm-i raiyyetlerin verib toprak sahibleri dahl edemezler. Amma konar göçer olmayub Yörüklükten bil-külliye feragat edüb davar ve öküzlerin dağıdub kâsibleri silkine münselik olub ziraat ve hirasetle meşgul olsalar, hîn-i tahrîrde on ylldan ziyade her kangl yerde sâkin bulunub yazllmuş ise resm-i raiyyetin defter mucebince ol karye sipahisine verir. Yörüklükten çıkmış olur, raiyyet olur." (Akgündüz, 1990: 229, 295; Saydam, 2009: 24-25) biçiminde Yörük taifesiyle alakalı bir kanunu anlatırken yer almıştır.

Sözcüğün mevcut şekliyle tespit edildiği yerlerden bir diğeri, 17. yüzyıl şairlerinden Karacaoğlan'ın Ala Gözlerini Sevdiğim Dilber adlı şiiridir. Aşı1k edebiyatının en önemli isimlerinden olan Karacaoğlan 1600'lü yılların ilk yarısında Çukurova-Toroslar hattında Yörükler arasında yaşadığı tahmin edilen bir şairdir. Özellikle şiirlerinde yöre halkının konuşma dilini kullanan Karacaoğlan'ın "konargöçer" ifadesini şiirlerine taşıdığ 1 görülür. Çünkü Karacaoğlan o yüzyıllarda konuşulan canlı dili şiirlerine taşımaya çalışmıştır. Karacaoğlan'ın Ala Gözlerini Sevdiğim Dilber adlı şiirinin dördüncü mısrası aşağıdadır (Öztelli, 1959: 78-79):

Karac'oğlan der ki yerim içerim

Ağır saltanatla konar göçerim 
Ahdım olsun seni alır kaçarım

Ferman çıkarsınlar var benim için (Karac'oğlan)

Konargöçer teriminin tespit edildiği yerlerden biri de Darendeli Kâtipzade Bakayi'nin Battal Gazi (Cafer)'nin Bizanslılara karşı yaptığı savaşları anlatan manzum destans1 eseri Battal Gazi Destanı'dır. 1769 y1lında yazımı bitirilen ve Sadrazam Silahdar Mehmet Paşa'ya sunulan eserde konargöçer sözcügü şu şekilde tespit edilmiştir (Tarama Sözlüğü, IV, 2009: 2630):

Bin eviz kabâillerdenüz biz

Konar göçer aşâirlerdenüz biz.

Sözcüğün konargöçer biçiminin yanında "konup göç-" şekli de Osmanlı döneminde tercih edilmiştir. Hünkar Hacı Bektaş-1 Veli'nin söylencelerine dayanan ve 15.-16. yüzyıllarda yazıya aktarılan 'Velâyetname-i Hacı Bektaş' adlı eserde Tatarlar olarak geçen Moğol hakanı Gülü Han Müslüman olduktan sonra Sultan Alaeddin'den yer istemiştir. Sultan Alaeddin'in ulular ve beylerle görüşmesi Velâyetname'de şu şekilde anlatılır: "Sultan 'Ala'addin dahı uluların ve biglerin katına cem' idüp anlar ile meşveret kilup Ulular ve bigler siz ne dirsiz ve nice idelüm? Anlara kışla ve yazla gerekdür ki fi'l-vaki ‘ anlar Tatar Kavmidür. Konup göçmege ögrenmişlerdür. Yaz ve kış bir yerde karar idemezler." (Malçok Meteer, 2012: 104). Bu metinde yaz ve kış aynı yerde durmayan ve Anadolu'ya geldikten sonra konup göçmeyi öğrendiği izah edilen Moğolların yaşam şekilleri anlatılırken kullanılan "konup göç-" ifadesinin kullanılması rastgele kullanılmış bir ifade olmamalıdır. Bu dönemlerde bu birleşik yapının kullanılması "konargöçer" sözcüğünün kullanım alanını devam ettirdiği anlamına gelir.

Konargöçer sözcüğü Osmanlı döneminde çok kullanılmamış gibi görünmektedir. Hatta bu konuyla alakalı Tufan Gündüz, "Osmanlı arşiv kayıtlarında konar göçer kavramı yerine "göçer, haymâne taifesi, göçebe taifesi, yörük, yörükân, Türkmen taifesi” gibi tabirler de geçer. ” (Gündüz, 2002: 161) değerlendirmesini yapmıştır. Bu durum Osmanlı Devletinin tercih ettiği bir uygulama olabilir. Halk arasında ve halk edebiyatı ürünlerinde "konargöçer" sözcüğü daha çok tercih edilmiş gibi durmaktadır. Osmanlı yazılı metinlerinde "göçer" ifadesi kullanıldığı için yapı ve anlam olarak bu sözcüğe çok benzeyen "konargöçer" sözcüğü çok tercih edilmemiş olabilir. Ayrıca yapılan yazılı ve sözlü araştırmalarda "Yörük, Yörükân, Türkmen" gibi terimlerin kavramsal olarak mevcut "konargöçer" sözcüğünün anlamını üzerinde taşıdığı için "konargöçer" sözcüğüne pek fazla ihtiyaç duyulmadığ 1 izlenimi oluşmuştur. Çünkü bu mevcut durum Anadolu Yörük/Türkmen grubu arasında da 
görülmektedir. Ama sonuç olarak Osmanlı döneminde "konargöçer" sözcügünün de kullanım alanını devam ettirdiği yazılı belgelerle sabittir.

Konargöçer sözcüğüne yap1 olarak benzer bir kullanım da 14.-15. yüzyıllarda yazıya geçirilse de sözlü gelenek olarak İslamiyet öncesi dönemde oluşmaya başlayan Dede Korkut Hikâyeleri'nde tespit edilmiştir. Dede Korkut Hikâyeleri'nden Dirse Han Oğlu Boğaç Han Boyu hikâyesinde yer alan; "Klşda yazda karı buzı erimeyen Kazılık Tağına geldi çıkdı. Alçakdan yüce yirlere çapup çıkdl. Baksa görse bir derenin içine karga kuzgun iner çıkar, konar kalkar. Bidevi atın çeledi, ol tarafa yorıdl.” (Ergin, 2009: 88) metninde kullanılan "konar kalkar" ifadesi tesadüfî bir kullanım olmamalıdır. Karga, kuzgun gibi etçil kuşların geçici şekilde et yiyebilmek için yere/zemine konup arkasından kalkmasını bu şekilde izah eden bir dil mantığının yaylak ve kışlaklar arasında mevsimsel döngülerle olan daha uzun göç hareketliliğini "konargöçer" şeklinde izah etmesi dil mantığı açısından doğru bir kullanım örneğidir.

Konargöçer sözcüğünün sözlüklerdeki anlamı incelendiğinde sözcük, Türkçe Sözlükte; "konargöçer: Göçebe bir hayat süren, bir yere sürekli yerleşmeyen (aşiret, oba vb.), göçerkonar" (Türkçe Sözlük, 2011: 1470) şeklinde yer alırken halk ağızlarından derlenen Derleme Sözlüğünde ise; "konargöçer: Çadırlarda göçebe hayatı yaşayan kimseler, göçebe (Samsun)" (Derleme Sözlüğü, IV, 2009: 2917) şeklinde yer alır. Tarama Sözlüğünde direkt konargöçer ibaresi yer almasa da "konar göçer evli: Göçebe" şekline sözlükte rastlanılmaktadır. Konar göçer evli terimi 1654 yılında Kâtip Çelebi tarafindan kaleme alınan Cihannüma'da; "Halk ekser ulus kavmi konar göçer evli taifedir." ve "Seyhun; İki tarafinda konar göçer evli Oğuz taifesi sakin olur, Müslümandır." (Tarama Sözlüğü, IV, 2009: 2630) şekillerinde kullanılmış ve Tarama Sözlüğüne girmiştir. Sözcük, Tevârih-i Âl-i Osman'da da; "Osman Gāzi'nin dedesi Süleyman Şah Gāzi Rum'a gelüp... kim konar göçer evler etrafa dağıldılardı" (Âşı Paşazâde Tarihi, 6-7) şekliyle yer almaktadır. Sözcük yine benzer bir kullanım örneğiyle: "Konar ve göçer evlü Beyliklü cemâ'atinden İsma'il nâm kimesne südde-i sa'âdetime gelüp..." (Anadolu, Karaman, Adana ve Mar'aş beylerbeyleri ile bu vilayetteki kadılara ve Halep Türkmenleri voyvodasına 3 Zilhicce sene 1047/18 Nisan 1638 tarihli hüküm: BA, MD, nr. 88, s. 80, hük. 211) (Şahin, 2020: 18) şeklinde Yörük/Türkmen grubu ilgilendiren bir kanun hükmünde tespit edilmiştir. Bu örneklerde hem "konargöçer" hem de "göçer evli” terimleri birlikte kullanılmış ve farklı bir kullanım şekli ortaya çıkmıştır.

Konargöçer sözcüğüne etimolojik açıdan bakıldığında hem ekler yönünden hem de kökler yönünden Türkçe bir sözcüktür. Sözcüğün oluşum şekli Türk dilinin mantığ 1 açısından kurulum olarak kolay bir sözcüktür. "Köç- (Göç-)" fiili yukarıda ilgili bölümlerde yeterince açıklandı. Burada daha çok "kon-" 
fiiline değinilecektir. Türkçenin ilk yazılı eserleri olarak 8. yüzyılda taşa kazınarak dikilen Orhun Yazitlarında kendine yer bulan ve Köktürk Türkçesinde; "kon-: Konmak, yerleşmek, konaklamak” (Ergin, 2006: 102) anlamına gelen bu sözcük, en eski sözcüklerden biridir. Köktürk Türkçesinin hemen sonrasında oluşan tarihi Türk lehçelerinden Uygur Türkçesinde; "kgon-: konmak, yerleşmek, durmak" (Gabain, 2003: 282) anlamlarında iken tarihi Türk lehçelerinden Karahanlı Türkçesinin önemli eseri Dîvânu Lügâti't-Türk'te: "kon-: 1. (kuş vb.) konmak; 2. (kabile vb.) konmak, inmek; konaklamak, yerleşmek" (Kaşgarlı Mahmud, 2018: 727) anlamlarındadır. Çağatay Türkçesinde "kon-: konmak, konaklamak" (Ünlü, 2013: 645) anlamlarıyla birçok Çağatay Türkçesi eserinde yer almıştır. Tarihi Türk lehçelerinden Harezm Türkçesinde de; "ķon-: konmak, bir yerde konaklamak, gecelemek" (Ata, 1997: 370) anlamındadır. Sözcük, tarihi Türk lehçelerinden Kıpçak Türkçesinde de; "ķon-: 1. Konmak, inmek, mola vermek; 2. Oturmak; 3. Çadır kurmak" (Toparl1, Vural ve Karaatl1, 2014: 153) şeklindedir ve Eski Anadolu Türkçesi eserlerinde de benzer anlamlarıyla yer alarak Selçuklu Türkçesi, Osmanlı Türkçesi ve Türkiye Türkçesine kadar ulaşmıştır. Bugün Türkiye Türkçesi yazı dilinde; "kon-: 1. Kuş, kelebek, uçak, toz vb. bir yere inmek; 2. Yolculukta geceyi geçirmek için bir yerde kalmak, konuk olmak; 3. Kısa bir süre için bir yere yerleşmek, bir yeri yurt edinmek; 4. Bir şeyi emeksiz edinmek" (Türkçe Sözlük, 2011: 1472) anlamlarıyla kullanım alanını devam ettiren "kon-" sözcüğü, Çağdaş Türk lehçelerinde de "konmak, yerleşmek" anlamlarıyla kullanılmaya devam edilmektedir. Kullanım serüveni açısından "köç- (göç-)" fiili de Köktürkçe döneminde yazılı dildeki yerini almış ve Türkiye Türkçesi devrine kadar ulaşmıştır.

"Kon-” ve "köç- (göç-)" fiilleri Türkçede yaygın bir kullanıma sahip olan “+Ar" sıfat fiil ekiyle ekleşmiş ve "konargöçer" sözcüğü meydana gelmiştir. Burada Türk halkının "konması" kuşların bir yere konması, günlük bir mekânda konaklanması ya da sürekli şekilde bir yere yerleşmek değildir. Metinlerden de tespit edildiği gibi Türklerin konup göçmesinde yayla, yaylak, klşla, kışlak, güzle, yayla-, kışla- terimleri önemli bir yer tutmaktadır. Türkler bu adlarla adlandırdıkları mekânlarda mevsimsel döngülerle belli bir süre kalmaktadırlar. $\mathrm{Bu}$ kaldıkları yerlerde söylenilenlerin aksine hem hayvanlarıla ilgilenirken hem de belli oranda tarım yapmaktadırlar. Önceden belli olan bu yerleri kolay kolay değiştirmeyen ve her sene aynı zaman diliminde aynı mekânlara gitmeye özen gösteren Türklerin yayla, kışla ve güzle arasındaki mevsimsel döngülerinin zaman dilimleri kolay kolay değişmemektedir. Bu mekânlar arasında göç yolu olarak belirledikleri yollarda 8-10 günlük yolculuklar yapılır ve bu yolculuklarda günlük/saatlik konaklamaların olduğu mekânlar da vardır lakin "kon-" fiili ile anlatılan yayla, kışla ve güzle'deki uzun süreli konma eylemidir. Selçuklu sultanı Sultan Alaeddin Keykubat'ın da kışlak olarak kullandığ 1 Alanya'ya gelirken Okurcalar Mahallesi'nde yer alan Alarahan 
Kervansarayı'nda konakladığı anlatılır. Bu tarz geçici konaklamalar Türk tipi göç faaliyetlerinin bir parçasıdır ama "konargöçer" teriminde yer alan konma eylemi ile anlatılmak istenenin "yaylamak, kışlamak ve güzlemek" için yapılan uzun sureli konma olduğu etimolojik olarak da anlaşılmaktadır.

Konargöçer sözcüğünün etimolojik yapısı, ilk Türkçe sözcüklerden olan "kon-” ve "köç- (göç-)" eylemlerinin tesadüfî olarak bir araya gelmediğini ve Osmanlı arşivlerine de tesadüfî olarak girmediğini ortaya koymaktadır. Bu sözcük hem etimolojik hem kavramsal hem de anlamsal olarak üzerine düşünülen ve bunun sonucunda türetilen bir sözcük hüviyetindedir.

Konargöçer sözcüğünün yapı ve anlam bakımından bir benzeri konargöçer sözcüğündeki "kon-" ve "köç- (göç-)" eylemlerinin yer değiştirmesi sonucu oluşan göçerkonar sözcüğüdür ve bu sözcük özellikle Osmanlı döneminde tercih edildiği eserlerden tespit edilen bir sözcüktür. Bu sözcügün geçtiği yerlerden birisi 18-27 Haziran tarihleri arasında Bacı kadısına gönderilen bir hüküm metninde; "Tâceddinlü cemâ'atinden kethüdâ Mahmud ve Veli dergâh-ı mu'allâma gelüp göçer konar halkuz, çiftümüz ve çubuğumuz yokdur, şimdiye dek bize teklîf-i avârız olunu gelmemişdir..." (Barkan, 1943: 280) şeklinde geçen metinde Taceddinli camaatinin kendilerini "göçer konar halkız" olarak değerlendirdiği görülür. Burada önemli olan kendi yaşam şekillerinin izahını bizzat kendilerinin dile getirmeleridir. Sözcüğün benzer örneği Osmanlı döneminde Bağdat beylerbeyine 2 Şubat 1545 tarihinde gönderilen Muhimme defterlerine de girmiştir ve bu defterde; "hâric vilâyetden göçer konar ulus taifesinden ra'iyyet tergîb idüb...” (Topkapı Sarayı Arşivi H. 951- 952 Tarihli ve E-12321 Numaralı Mühimme Defteri, Yayınlayan: Halil Sahillioğlu, İstanbul 2002, 167-168; Akt. Şahin, 2020: 18) şeklinde geçmektedir.

Türkiye Türkçesi yazı dilinde; "göçerkonar: Konargöçer: göçerkonar aşiret" (Türkçe Sözlük, 2011: 955) şeklinde konargöçer anlamıyla kullanılmaya devam eden göçerkonar sözcüğü de etimolojik açıdan konargöçer ile aynı düzlemdedir. Göçerkonar sözcüğü, konargöçer sözcüğüne göre günümüzde dil mantı̆̆ 1 çerçevesinde çok fazla tercih edilmemektedir.

\section{Genel Değerlendirme ve Sonuç}

$\mathrm{Bu}$ çalışmamızda Eski Türkçe "köç- (göç-) / köç (göç)" sözcüklerinden türeyerek oluşan göç, göçebe, göçer, göçer evli/evlü, göçer oba, göçgün/göçkün, göçgüncü/göçküncü, göçmen/göçmel ve konargö̧̧er/göçerkonar sözcüklerini hem anlam hem kavram hem etimoloji açısından değerlendirmeye çalıştık. Bu sözcükler özellikle Türk hayat yapısının merkezinde yer alan ve Türklerin geçmişten günümüze yapmış oldukları göç faaliyetlerini anlatan sözcüklerdir. İlk Türklerde özellikle Göktürklerin yaylaklar ve kışlaklar arasında başlayan bu macerası günümüze kadar devam etmiştir ve Yörük/Türkmen grup, mevsimsel döngülerle 
yaylak ve kışlak olarak belirledikleri mekânlar arasında hayvanlarıyla birlikte göçmeye devam etmektedirler. Yaz aylarında yayla olarak belirledikleri yerlerde özellikle kıl çadırlarda kalan Yörük/Türkmen halkı kışın kışlak olarak belirledikleri sicak sahillere/yerlere inerek/dönerek orada hem hayvancilık hem de tarım yapmaktadırlar. Türk tipi göç faaliyetleri sadece hayvanları merkeze alan bir göç faaliyeti olarak düşünülmemelidir. Türk tipi göç faaliyetleri hem tarımı hem de hayvancılığı kapsamaktadır. Bu şekliyle Türk tipi göç faaliyetlerini Bedevi Arapların ve Çingenelerin göç faaliyetlerinden ayırmak gerekir. Bedevi Araplar ve Çingeneler düzensiz bir göç faaliyeti içindeyken Türklerin önceden gidecekleri yayla, kışla ve güzle bilinmektedir. Tüm bu göç faaliyetleri için geçmişten günümüze kullanılan sözcükleri ele aldığımız bu çalışmamız ortaya koymuştur ki Türk tipi göç faaliyetleriyle ilgili en eski Türkçe sözcük, konargöçer sözcügüdür. Bu sözcük ilk olarak Uygurlar döneminde 753 y1lında Göktürk Alfabesiyle yazılan Taryat (Terhin) yazıtlarında yer almış ve sonrasında Türk tipi göç faaliyetleri için günümüze değin kullanılmıştır. Bu sözcüğün yanında göçer, göçer evli/evlü, göçmel, göçmen, göçgün, göçkün, göçgüncü, göçküncü, göçerkonar sözcükleri de yine Türk tipi göç faaliyetleri için kullanılmışlardır. Göçer sözcügü̈ daha eski olmakla birlikte ele aldığımız diğer sözcükler özellikle 14.-15. yüzyıllardan itibaren yazılı belgelere girmiştir. Görülen odur ki etimolojik kökeni de tartışmalı olan göçebe sözcüğü daha geç dönemde kullanılmaya başlanmıştır. Son yıllarda daha popüler bir kullanıma ulaşan göçebe sözcüğü ile konargöçer sözcüğü arasında bir rekabet oluşmuştur ve bu rekabete yer yer göçer sözcüğü dâhil olmuştur. Göçer sözcügü bu rekabette özellikle konargöçer sözcügünün yerine veya onun yanında kullanılmıştır.

Türk tipi göç faaliyetleri açısından bakıldığında son yıllarda özellikle Yörük/Türkmen gruplar göç temelli sözcüklerin merkezine yerleşmiş durumdadırlar. Elde edilen verilerden hareketle bu sözcüklerin Yörük/Türkmen gruplarla olan bağlantısına bakmakta fayda vardır. Yörük/Türkmen gruplar için kullanılan göç merkezli sözcüklerin bu kadar fazla olmasında Türk tipi göç faaliyetlerini anlatırken bu sözcüklerin dönüşümlü kullanılmasının etkisi göz ardı edilmemelidir. $\mathrm{Bu}$ sözcüklerin dönüşümlü kullanılması da Türk tipi göç faaliyetlerinin adlandırılmasında terminolojik hataları ortaya çıarmaktadır. Yörük/Türkmen grup üzerine çalışmalar yapan araştırmacıların özellikle konuya kavramsal açıdan bakmadan önceki söylenilenleri devam ettirmeleri de bu terminolojik hataları daha da derinleştirmektedir. Burada öncelikle konargöçer ve göçebe sözcüklerinin tercih edilmeleri noktasında araştırmacıların tutumuna bakmak gerekir. Araştırmacıların çoğunun konargöçer sözcüğü üzerine yoğunlaştıkları görülür. Yörük/Türkmen halk1 üzerine önemli çalışmaları olan Mehmet Ak, oryantalist gezginlerin Yörük/Türkmen gruplarını nitelemek için göçebe kavramını kullandıklarını izah ederek; "göçebenin belirli bir mekânı bulunmadığ 1 gibi göçebelik, Türk hayat tarzını ifade edemez. Yörük/Türkmen gruplarının kışla, yazla, yayla ve güzle döngüsü içerisinde mevsim farkına bağlı her yıl tekrarlanan yer değiştirme süreci ile hareket alanlarının sınırları, kanunlarla çizildiği gibi başıboş hareket edemezler. Yurt adı ile geniş kapsamlı bir yer 
olgusuna sahip kültür, göçebe olarak adlandırılamaz. Ayrıca Yörük/Türkmen halkı da kendilerini göçebe olarak nitelendirmez. Yörük, Türkmen, konargöçer gibi kavramları bir kenara bırakıp; Yörük/Türkmen hayatını bunlardan dağ göçebeliği ve yarı göçebelik gibi terimler ile göçebe imgesi içerisine sıkıştırmak mümkün değildir." (Ak, 2021: 34, 38) değerlendirmesini yapar. Ak (2021), net olarak Yörük/Türkmen grupların konargöçer, Yörük, Türkmen gibi terimlerle nitelendirilmelerini doğru bulduğunu, göçebe sözcüğünün ise Yörük/Türkmen grupları nitelemediğini anlatmaya çalışmaktadır. Ak (2021)'ın söylediklerinden anlaşılan burada anlatmak istediği durum Batılı oryantalistler bilinçli olarak Türk tipi göç faaliyetlerinin adına göçebe demişlerdir ve Türk tipi göç faaliyetlerini Bedevi Arapların göç faaliyetleri ile aynı düzleme koymaya çalışmışlardır. Gökbilgin (1957) de benzer görüştedir ve "Göçebe teriminin, Yörük/Türkmen kavramının karşılığı olamayacağını Yörük/Türkmen halkının hareket halinde oldukları zamanlarda da göçebe adını almalarının mümkün olmadığını dile getirmektedir. Göçebe terimi bir halk grubu için vasıfken; Yörüklüğün aslen yaşayış tarzı ve etnik bir asıl da gösterdiğini ifade etmektedir." (Gökbilgin, 1957: 4). Tufan Gündüz (2002: 161) ve Latif Armağan da (1999: 142-150) konargöçer terimini kullanan araştırmacılardandır. Ali Sinan Bilgili (2000: 32) de Anadolu'da Türk tipi göç faaliyetlerini sürdüren Varsaklar'ı konu ettiği çalışmasında “...konar göçer hayatın gerekli kıldığı yaylak-kışlak hareketi..." şeklinde konargöçerlik ile yaylakkışlak kavramının aynı manaya geldiğini anlatmaya çalışır. Mehmet İnbaşı (2000: 145-146) ve Ersin Gülsoy (2000: 122) da Ali Sinan Bilgili gibi konargöçerliği yaylak-kışlak kavramıyla bir düşünmektedirler. Yusuf Halaçoğlu da konargöçer sözcügünü tercih eder ve “... konar-göçerlerin bu hayat tarzı, göçebe hayat yaşayan diğer uluslardan büyük farklılık göstermektedir. Gerçek anlamda göçebe yaşayan aşiretlere nazaran bazı konargöçer grupların yazın hayvancılıkla uğraşmaları yanında, kışlıklarında ekinlik yani bir nevi küçük ziraat yaptıkları göz önünden uzak tutulmamalıdır." (Halaçoğlu, 1988: 4; Halaçoğlu, 2009: XVI) der. Buradan Halaçoğlu'nun incelemiş olduğu Osmanlı tahrir defterlerinde bazen ziraat bazen de çoban olarak işlenen Yörük/Türkmen grupların hem hayvancıllğı hem de tarımı birlikte yaptıklarını tespit ettiği izlenimi oluşmaktadır. Şenol Çelik de konargöçer sözcügüüü tercih eder ve konargöçerlik ile Yörüklüğün aynı şey olduğunu anlatarak; "konargöçer veya Yörük olarak adlandırdığımız nüfus" (Çelik, 2000: 85) ifadesini kullanır. Cengiz Orhonlu da; "Hayvancıllk ve tarımla uğraşan Yörük/Türkmen grupları hayat tarzları itibari ile göçebe değillerdir, resmi kayitlarda ve kanunnamelerde geçtiği şekli ile konargöçer olarak nitelendirilmeleri gerekir.” (Orhonlu, 1963: 13) der. Hanefi Bostan, Karadeniz'de yaşayan Yörük/Türkmen gruplardan Çepnileri konu edindiği çalışmasında, "XV. ve XVI. yüzylllarda Anadolu'da Karadeniz'e sahili bulunan sancaklarda küçümsenmeyecek oranda konar göçer grupların yanında, birçok iskân biriminin Oğuzlar'a ait boy, oymak ve cemaat adlarını taşıması yöreye yoğun bir Türkmen nüfusunun yerleştiğinin göstergesidir.” (Bostan, 2000: 69) şeklinde izahta bulunurken konargöçer kavramını tercih eder. 
Sadetttin Gömeç de direkt Yörük/Türkmen grupları ifade etmeyip; “Türkler için bugüne kadar yarı göçebe terimi kullanıldı. Konargöçer terimi ile benzeşmekte ise de Türkler için konargöçer deyimini kullanmak daha doğru" (Gömeç, 1995: 82) diyerek konargöçer sözcüğü yanında tarafını alır. Burada Saadettin Gömeç'in özellikle ilk Türkleri 'yarı göçebe, avcı toplayıcı, hayvancılıkla uğraşan, göçebe millet' gibi kavramlarla tanımlayan araştırmacılara bir göndermede bulunduğu anlaşılmaktadır.

Sadece konargöçer terimini kullanan araştırmacıların yanında sistemli şekilde terminolojiyi dikkate alarak hem göçer hem de konargöçer terimlerini birlikte kullanan araştırmacılar da tespit edilmiştir. Bu kavramlara bazen göçerkonar teriminin eklendiği de olmaktadır. Üçler Bulduk, hem konargöçer hem de göçer terimini birlikte kullanmayı tercih eden araştırmacılardandır (Bulduk, 2008: 217). Şeyda Büyükcan Sayılır, Göçebelik, Konar-Göçerlik Meselesi ve Coğrafi Bakımdan Konar-Göçerlerin Farklılaşması isimli çalışmasında; "konargöçerler, göçebelik ile yerleşik hayat arasında bir ara yaşam tarzıdır. Çalışmamızda konargöçer ve göçer terimlerini birlikte kullanılması daha uygun görülmüş̧ür." (Büyükcan Sayılır, 2012: 568) diyerek hem konargöçer hem de göçer sözcügünü̈ birlikte tercih edenlerdendir. Anıl Yılmaz ve Cahit Telci de Türk Kültür Terminolojisinde Göç Kavramı adlı çalışmalarında; "Türklerin yerleşiklik öncesi hayat tarzlarının göçerlik ya da göçerkonarlık kavramı içinde değerlendirilmesi gerekmektedir. Dolayısı ile bilimsel çalışmalarda göç eden Türk boyları için kullanılan göçebe teriminin kullanılmasının terminolojik bir takım eksiklikler hatta yanlışlıklar içerdiğini; bu kelimenin yerine 'göçer' ya da 'göçerkonar' terimlerinin tercih edilmesi gerektiğini düşünmekteyiz." (Yılmaz ve Telci, 2010: 26) diyerek göçebe sözcüguüne karşı göçer ve göçerkonar sözcüklerinin tercih edilmesi gerektiğini izah etmeye çalışırlar.

Sadece göçer terimini tercih eden araştırmacılar da tespit edilmiştir. Muhtar Kutlu (Kutlu, 2000: 211) tek başına göçer kavramını tercih eden araştırmacılardandır. Tuncer Baykara da göçer kavramını kullanmayı tercih eden araştırmacılardandır. Baykara (1987); "Türklerin göçerliği sürekli başıboş ve serseriyane bir göçerlik olmayıp belli yaylaklar-kışlaklar zaman zaman da güzleler arasında cereyan eden bir göçerliktir." (Baykara, 1987: 398) şeklinde hem göçer sözcügü yanında tarafını seçmiştir hem de Türk tipi göç faaliyetlerinin başıboş bir göç faaliyeti olmadığını, belli mekânlar ve mevsimler arasında geliştiğini açıklamaya çalışır.

Göçebe sözcüğünü tercih eden araştırmacılara bakıldığı zaman bu sözcüğü Türk tipi göç faaliyetleri açısından reddeden araştırmacıların yanı sıra terminolojik tartışmalara hiç girmeden bu sözcüğü konargöçer sözcüğü ile ayırmadan birlikte kullanan araştırmacılar da mevcuttur. Özellikle İlhan Şahin, göç merkezli tüm sözcüklerin Türk tipi göç faaliyetleri için kullanıldığını izaha çalışır ve bu durumu; "Türkçede "göç-" fiilinden türeyen ve kaynak eserler ile arşiv belgelerinde 'göçer', 'göçer Türkmen', 'göçer Yörük', 'konar göçer', 'göçer konar', 'göçer ev', 'göçer 
evler', 'göçer evli', 'göçebe', 'göçebe yörükler', 'göçebe Türkmenler', 'köçkün/göçgün', 'göçmel', 'yörük' ve 'Türkmen' vb. şeklinde geçen bu kelime veya terimler, özünde aynı anlama gelen ve her yıl mevsimsel döngülere göre kışla, yazla, yayla ve güzlelerinde düzenli bir şekilde dönemsel hayat tarzını yaşayanları ifade eden kelime veya terimlerdir." (Şahin, 2020: 23) biçiminde anlatmaya çalışır. Faruk Sümer de benzer şekilde; "Anadoluya Yalnız Göçebe Türkler mi Geldi?" isimli çalışmasında ilk Türklerden Oğuz Türklerine uzanan çalışmasında; "Gök Türkler'in, göçebe olmakla beraber, çiftçiliğe ehemmiyet verdikleri görülüyor. $\mathrm{Bu}$ ırkın önemli bir eli olan Oğuzlar da böyle idi. Yani, onların önemli bir bölümü tam göçebe, bir bölümü yarı göçebe, bir bölümü de şehir ve köylerde oturak hayatı yaşıyordu. Yalnız göçebelerin sayısının oturaklardan daha fazla olduğu muhakkaktır." (Sümer, 1960: 568, 574) şeklinde sadece göçebe terimini kullanmayı tercih etmiştir. Ayrıca Sümer, yarı göçebe ve tam göçebe terimlerini de kullanmıştır. Mehmet Beşirli de, 'göçebe'yi tercih edenler arasındadır (Beşirli, 2003: 289-307). Cevdet Türkay, Osmanlı arşiv belgelerinden hareketle oluşturduğu çalışmasında Yörük/Türkmen grupların Osmanlı coğrafyasındaki dağılımlarını ifade ederken, hemen hemen göç merkezli tüm sözcükleri tercih etmiştir. Cevdet Türkay çalışmasında göçebe taifesi (Türkay, 1979: 61), göçer evli (Türkay, 1979: 103), konar göçer ve göçebe terimlerini bir arada (Türkay, 1979: 98), göçer (Türkay, 1979: 106), konar göçer Türkman yörükânı (Türkay, 1979: 385) ve konar göçer Türkmen ekrad-1 yörükânı taifesi (Türkay, 1979: 394) gibi terim ve kavramları birlikte kullanmıştır. Öngör (1964) de, göçebe terimini tercih edenlerdendir. Öngör; "İnsanların hayvanları ile birlikte durmadan uzun mesafeler boyunca yaptıkları yer değiştirmeler, mevsimlere uyarak çok defa belli bir güzergâhı izler. Daimilik karakteri taşıyan bu yer değiştirmelere "göçebelik" (nomadizm), bu hayatı süren insanlara da "göçebe" (nomad) denir." der. Sebahattin Şimşir, Şah İsmail'i ele aldığı çalışmasında ve İsmail Aka da yine İran'dan yapılan göçlerle ilgili çalışmasında Safevi Devleti'nden bahsederlerken; "Safevi Devleti, Anadolulu göçebe ve köylü Türkler tarafindan kurulmuştur." (Şimşir, 2019: 85; Aka, 2003: 60) şeklinde Anadolu Türklerini göçebe terimi ile ilişkilendirmişlerdir.

Konargöçer, göçerkonar, göçebe, göçer, göçer evli, göçgün/göçkün, göçgüncü/göçküncü, göçmel, göçmen gibi terimlerin yanında Türk tipi göç faaliyetlerini dağ göçebeliği, yarı göçebelik (Eröz, 1991: 71-72; Denker, 1960: 138), tam göçebe, yarı göçebe (Sümer, 1960: 574) yatay göçebelik, dikey göçebelik (Büyükcan Sayılır, 2012) gibi terimler içerisinde değerlendirenler de vardır. Özellikle bu yarı göçebe terimi ile ilgili Anıl Yılmaz ve Cahit Telci (Yılmaz ve Telci, 2010: 22); "Semi-nomad gibi sonradan yakıștırmalar yapıldığını da belirtmek isteriz. Bu semi-nomad ifadesi maalesef Türkçede yarı göçebe gibi bir kavramın türemesine neden oldu." değerlendirmesini yaparlar. Bu yarı göçebe, tam göçebe gibi kavramları Mehmet Ak (Ak, 2021: 39) ve Saadettin Gömeç (Gömeç, 1995) de kabul etmez. Bu terimler türetilirken Batı'nın sözcük türetimlerinden etkilenildiği aşikârdır. Bunun yanında Türk tipi göç faaliyetlerinin tam olarak anlaşılamadığ ve Türk tipi göç faaliyetlerinin sadece hayvancılıkla uğraşılması, hem tarım yapılıp hem hayvancılıkla uğraşılması, coğrafi mekân olarak ova ve dağlara farklı göçler 
yapılması gibi farklı farklı yorumlandığı görülmektedir. Yörük/Türkmen grupların göç faaliyetlerini farklı döngüler şekillendirmektedir. Ayrıca Yörük/Türkmen grupların Anadolu'da hem hayvancılığ hem de tarımı birlikte götürdükleri yapılan araştırma gezilerinden de anlaşılmaktadır. Mehmet Ak'ın da belirttiği gibi, "Konargöçer hayat içerisinde tarım ve hayvancılığın bütünleşmiş olduğunu anlayamadıkları için mevcut durumu farklı terimlerle anlamlandırma eğilimine girip, genellemelere gitmişlerdir.” (Ak, 2021: 38). Bu sebeplerden ötürü Türk tipi göç faaliyetlerinin yarı göçebelik, tam göçebelik, dağ göçebeliği, ova göçebeliği, yatay göçebelik, dikey göçebelik gibi adlarla adlandırılmaları doğru değildir. $\mathrm{Bu}$ adların yanında Türk tipi göç faaliyetlerinin merkezini teşkil eden Yörük/Türkmen grupları kastederek, "Yörükler için göçebe-hayvancılık (pastoral nomadizm, pastoral göçebelik vb.) terimi tam karşıllı̆ııı bulmaktadır." (Ürker ve Çobanoğlu, 2014: 153) gibi bir değerlendirmede bulunup pastoral göçebelik gibi bir terim türetimin literatürde bir karşllığı olabilir lakin Yörük/Türkmen gruplar için bir karşılı̆g 1 bulunmamaktadır. Yapılan araştırmalar sonucu özellikle Yörük/Türkmen gruplar üzerine sahada yapılan araştırmalar da göstermiştir ki Türk tipi göç faaliyetleri yazları yayla olarak adlandırılan yüksek dağlara yapılırken, önce Ekim ayı gibi güzle olarak bilinen daha aşağıdaki yerlere ve kışları da epey sıcak olduğu düşünülen sahil bölgelerine ve ovalara yapılmaktadır. Kışları ovalarda tarım da yapılmaktadır. Bu faaliyetleri gerçekleştiren Yörük/Türkmen grupları adlandırırken kelimelerin terminolojik boyutlarına bakılmadığı ve Türk tipi göç faaliyetlerinin bu dar kalıpların içine sıkıştırılmaya çalışıldığı görülmektedir.

Kavramsal ve anlamsal boyutlarına bakmaya çalıştığımız göç merkezli sözcüklere etimolojik olarak da bakmaya çalıştık. Etimolojik olarak kökeni tartışmalı olan sadece "göçebe" sözcüğüdür. Göçebe sözcüğünün oluşumuyla alakalı Rus Türkolog Wilhelm Radloff bilim dünyasını yanlış yönlendirmiş olmalıdır. Bu yanlış yönlendirmeyle alakalı İbrahim Kafesoğlu (Kafesoğlu, 2005: 32-35) da hemfikirdir. Kafesoğlu, "Onun, Rus hegemonyası altında kalan Türkler üzerine yaptığ 1 incelemelere dayanarak Türk sosyal hayatı ve devlet nizamına dair ileri sürdüğü düşüncesi, basit ve mahallidir.” (Kafesoğlu, 2005: 32-35) değerlendirmesinde bulunur. Wilhelm Radloff, etimolojisini yaparken Türkçenin gramer özelliklerini ikinci plana atarak özellikle Rus bakış açısıyla bir değerlendirme yapmış olmalıdır. Mehmet Ak, Batılı Gezginlerin Yörük/Türkmen İmgesi adlı çalışmasında Batılı oryantalistlerin göçebe sözcüğünü bir niteleme aracı olarak kullandıkların belirtir (Ak, 2021: 34). Oryantalizm her dönemde yoğun bir şekilde etkisini hissettirmiştir. Wilhelm Radloff, bir Türkolog olmakla birlikte göçebe terimini ele alırken Batılı bakış açısından kurtulamamış gibi görünmektedir. Göçebe sözcüğünün etimolojisi konusunda Gerhard Doerfer de Wilhelm Radloff ile aynı görüştedir. Wilhelm Radloff”'un kelimenin "g̈öč+oba"dan türetilerek ortaya çıktığı ifadesini kabul eden Doerfer, sözcüğün "köč=ōpa" "köčȫpä" (köčōba) > köčőbä > göčäbä > göč=ōpa aşamalarından geçerek ortaya çıktığını belirtir." (Doerfer, 1967: 187). Sevan Nişanyan da Etimoloji Sözlüguünde sözcüğün 'göç-oba' biçimine göndermede bulunmaktadır (Nişanyan:https://www.nisanyansozluk.com/?k=g\%C3\%B6\%C3\%A7men\&lnk=1). 
Bu değerlendirmeleri İlhan Şahin (2020: 19) gibi birçok araştırmacı direkt kabul etmektedir. Hatta Şahin (2020), konuyu Anadolu ağızlarına getirerek; "Bu durum kuvvetli bir ihtimalle Anadolu Türkçesinde "göç-oba"nın ağızdan ağıza söylene söylene 'göçebe' haline dönüştüğü intibaını vermektedir." (Şahin, 2020: 19) der. Şahin, 'göç-oba' şeklinde türediğini izah ettiği göçebe sözcüğünün ikinci parçası olan oba sözcüğüne göndermede bulunarak; "Türkçede "oba", Moğollarda "obog" olarak bilinen terim, aileden birazcık büyük ve birbirine kan bağı ile bağlı idarî ve sosyal yapılanmaları ifade eder. Dolayısıyla bu hayatı yaşayanlar için kışla, yazla, yayla ve güzle arasında gerçekleşen göç hareketleri ve konaklamalar obalar halinde olur." (Şahin, 2020: 19-20) değerlendirmesini yapmıştır.

Peki göçebe sözcüğü gerçekten yukarıdaki şekilde oluşmuş olabilir mi? $\mathrm{Bu}$ ihtimalleri göçebe sözcüğü bölümünde değerlendirdik. Wilhelm Radloff, Gerhard Doerfer ve Sevan Nişanyan'ın göçebe sözcüğü ile alakalı yaptıkları değerlendirme Türkçenin gramer özellikleri açısından uygun değildir. Yani Türkçede iki adın ek almadan birleşmesi mümkün değildir. İlgili bölümde de belirttiğimiz gibi sözcügün illa Türkçe olduğu düşünülüyorsa veya Türkçe olması isteniyorsa "göçer oba, göç obası" gibi değerlendirmeler yapılması daha doğrudur. Hatta bu durumla alakalı Eyüboğlu sözcüğün "köçer oba (göçen ev)" dan türediğini ve köçeroba > köçebe $>$ göçebe > göçebe şeklinde gelişim gösterdiğini de bildirir (Eyüboğlu, 1988: 139). $\mathrm{Bu}$ durum düşme eğilimindeki sızıcı " $\mathrm{r}$ " sesinin yapısından dolayı gelişebilir. Lakin sözcügün bir anda ortaya çıkmış olması bu değerlendirmeleri de havada bırakmaktadır. Doğal olarak bu sözcüğün Anadolu ağızlarında söylene söylene göçebe halini aldığı değerlendirmesi de havada kalmaktadır. Yazılı eserlere ilk defa Osmanlı döneminde 18. yüzyılla birlikte girmeye başlayan bir sözcüğün ne zaman oluşmaya başladığ1 ve ne kadar sürede söylene söylene göçebe halini aldığı net değildir. Bir sözcügün Anadolu ağızlarında söylene söylene farklı bir hâl alması çok uzun yıllar gerektirir. Yazılı eserlerde ilk defa 18. yüzyılda görülmeye başlayan bir sözcük, yüksek ihtimalle Batılı dillerdeki bir sözcüğe karşllık olarak o an eldeki malzemelerden türetilmiş bir sözcük olabilmekle birlikte komşu dillerden Türkçenin gramer özelliklerine uyarlanarak alınmış bir sözcük de olabilir. Özellikle Farsçada 13. yüzy1ldan itibaren Türkçe kökenli "köç (göç)" sözcüğü gerçek anlamını koruyarak "kûç kerden" şeklinde kullanılmaya başlanmıştır. Bu fiil Farsçada hala kullanılmaktadır. Bu durumdan yola çıkılarak ilgili bölümde de belirttiğimiz gibi Osmanlı Türkçesi döneminde Arap ve Fars tipi göç faaliyetlerini karşılamak için sözcük, Farsçadan tekrar "kuc-abe, koc-abe, kûç-abe" biçimlerinde geri alınmış ve zamanla "kucabe > köcabe > köçabe > göçabe > göçebe" şeklinde kendisine kullanım alanı oluşturmuş olabilir. Bunun yanında sözcük direkt Türkçedeki "köç (göç)" sözcüğüne Farsça kökenli "cemaat, aşiret, topluluk" anlamlarına gelen "abe" sözcüğünün eklenmesi şeklinde de vuku bulmuş olabilir. $\mathrm{Bu}$ durumun olma ihtimali, Wilhelm Radloff, Gerhard Doerfer ve Sevan Nişanyan'ın etimolojik değerlendirmesine göre daha yüksektir. Wilhelm Radloff, Gerhard Doerfer, Sevan Nişanyan gibi Batılı Türkologların Türkiye'deki bazı araştırmacılar tarafından da desteklenen göçebeyle ilgili etimolojik görüşlerine Mehmet Ak, "W. Radloff ve G. Doerfer gibi oryantalistlerin görüşü çerçevesinde, 
göç ve oba kavramlarının birleşmesinden göçebe gibi bir çıkarımla bu terim savunulamaz." (Ak, 2021: 37) der. Bu görüşünü "Göçler sadece obalar halinde değil: oba, oymak ve boy halinde de yapıldığı gibi beyler tarafindan sevk ve idare edilerek belirli bir düzen içerisinde yürütülmüştür. Diğer çağdaş Türk lehçelerine başvurulup gösterilen örneklerde de göçebe çıarımını destekleyen bir terim bulunamaz. Osmanlı Devleti resmi belgelerinde, göçebe terimine, diğer terimler ile kıyaslandığı zaman çok fazla yer verilmemiştir. Ayrıca Yörük/Türkmen halkı da kendilerini göçebe olarak nitelendirmez.” (Ak, 2021: 37-38) biçiminde sağlamlaştırmaya çalışır. Yörük/Türkmen halkının "Yörük" veya "Türkmen" terimlerinin (özellikle Yörük) yaşam şekillerini ifade etmede yeterli olduğunu düşünerek göç merkezli sözcükleri çok fazla tercih etmemeleri Ak (2021)'ın bu görüşünü destekler. Ak (2021)'nn görüşleri kavramsal ve anlamsal olarak değerli olmakla birlikte etimolojik açıdan yeterli değildir. Lakin Türk tipi göç faaliyetlerinin sadece obalar halinde yapılmadığ 1 doğrudur. Osmanlı resmi belgelerinde "göçebe" teriminin çok fazla yer bulmaması, tarihi ve çağdaş Türk lehçelerinin hiçbirinde bu sözcüğün yer almaması ve Yörük/Türkmen grupların kendilerini göçebe olarak tanımlamamaları önemli ayrıntılardır. Tüm bu anlattıklarımızdan hareketle denilebilir ki "göçebe" sözcüğünün bazı Batılı ve Türk araştırmacıların söylediği gibi "göç-oba" birleşiminden meydana gelmesi zorlama bir görüştür. Türkiye Türkçesi ağızlarında çok fazla kullanılmayan hatta Derleme Sözlügü benzeri halk ağzıyla ilgili eserlerde de kendine yer bulamayan bir sözcüğün Türkiye Türkçesi ağızlarında söylene söylene "göçebe" halini alması beklenemez. Halk ağızları, bünyesindeki sözcükleri uzun yıllar değiştirmeden taşıyan sağlam yapılardır. Misal Karahanlı Türkçesi döneminden beri var olan "bıldır" sözcüguünü değiştirmeden bu günlere getiren halk ağızlarının "göç oba" sözcüğünü 150-200 yıllık bir zaman diliminde değiştirmesi çok zordur. Ne var ki sözcüğün ne ilk hâli ne de değişime girdiği hâli halk ağızlarında mevcut değilken sadece değişmiş halini halk ağızlarına bağlamak akademik açıdan yeterli değildir. "Göçer oba, göç obası" gibi sözcüklerin ise bir anda göçebe olması zor ihtimaldir. Göçebe sözcügünün İngilizce nomad sözcüğüne karşıllk olarak türetilmiş olma ihtimalinin yanında Arap ve Fars tipi göç faaliyetlerini karşılamak için Farsçaya verilen "kûç" sözcüguünün geri alınması ve bünyesine "-abe" ekinin eklenmesiyle "kuc-abe, koc-abe, kûç-abe" biçimlerinde oluşumu sonrası zamanla "kucabe > köcabe > köçabe > göçabe > göçebe" şekillerine dönüşmüş olma ihtimali çok yüksektir. Göçebe sözcügünün Türkçe kökenli veya yabancı kökenli olması etimolojinin işidir. Sözcük, kavramsal ve anlamsal olarak kullanılıyorsa artık Türkçeleşmiş demektir. Burada önemli olan sözcügün çok uzun yıllar yazılı belgelere girememiş olması, tarihi ve çağdaş Türk lehçelerinde yer almıyor olması ve Türk tipi göç faaliyetlerini karşılamayan bir kavram olduğunu düşünen araştırmacıların sayısının azımsanmayacak derecede çok olmasıdır. Sözcüğün Osmanlı döneminde (Anadolu sahasında) bir anda ortaya çıkmış olması da karşııt görüşleri destekler niteliktedir.

Göç merkezli sözcüklerden kökeni tartışmalı olmasa da hem "+mAl" ekinin durumu hem de kavramsal açıdan günümüzdeki anlamı değişen göçmel ve göçmen sözcüklerine bakıldı̆̆ında, bu sözcükler de belli bir zaman Türk tipi göç 
faaliyetlerini karşılamak için kullanılmıştır. Hatta göçmel sözcüğü hâlâ Türkiye Türkçesi ağızlarında Türk tipi göç faaliyetleri için kullanılmaktadır. “+mAl” ekinin çok fazla kullanılan bir ek olmaması ekle ilgili soru işaretleri doğursa da elde edilen veriler 1şığında eki Türkçe kökenli olarak kabul etmek gerekir. Kavramsal açıdan değerlendirildiğinde günümüzde bu sözcüklerden göçmen sözcüğü kendi ülkesini terk edip başka bir ülkeye yerleşen muhacir (kimse, aile veya halk) için kullanılmaktadır.

Göçgün, göçkün, göçgüncü, göçküncü, göçer, göçer oba, göçer evli/evlü sözcükleri etimolojik olarak Türkçe gramer özelliklerine uygun sözcüklerdir. Bu sözcükler Türk tipi göç faaliyetleri için uzun süre kullanılmıştır ve bazıları hâlâ kullanılmaya devam etmektedir. Özellikle göçer sözcügü hâlâ etkin bir şekilde varlığını devam ettirmektedir. Göçgün sözcüğü, Türkiye Türkçesi ağızlarında ve göçkün sözcüğü de hem Türkiye Türkçesi ağızlarında hem de standart Türkiye Türkçesinde Türk tipi göç faaliyetleri için kullanılmaktadırlar. Lakin kullanımları çok yaygın değildir. Ayrıca göçgün sözcüğü Türkiye Türkçesi gramer kurallarına uygun değildir ve ek olarak standart Türkiye Türkçesi yazı dilinde yer alan göçkün sözcüğünün "ihtiyar, ölümü yakın” gibi anlamları Türk tipi göç faaliyetleri anlamının önündedir. Yuvarlak ünlülü göçer evlü sözcüğü, Türkiye Türkçesi gramer kurallarına uygun değildir. Göçer evli ve göçer oba sözcükleri de Türk tipi göç faaliyetleri için günümüzde pek kullanılmayan sözcüklerdendir.

Göç merkezli sözcüklerin çağdaş Türk lehçelerindeki kullanımlarına bakıldığında, sözcükler Azerbaycan Türkçesinde 'köçäri' (göçeri), Başkurt Türkçesinde "küsmä halık" (küsme halık), "küskinsilär" (küskinsiler), Kazak Türkçesinde "köşpeli" (köşpeli), "köşpendiler" (köşpendiler), Kırgız Türkçesinde "köçmön” (göçmen), Özbek Türkçesinde "köçmänçi” (göçmenci), Tatar Türkçesinde "küçmä halı" (küçme halık) Türkmen Türkçesinde "göçmen" (göçmen), Yeni Uygur Türkçesinde “köçmän” (göçmen)'dir (Ercilasun, 1991: 278279). Türkiye Türkçesinde çok tartış1lan konargöçer ve göçebe terimleri çağdaş Türk lehçelerinde mevcut değildir. Yukarıda da bahsedildiği gibi özellikle göçebe teriminin çağdaş Türk lehçelerinin hiçbirinde olmaması bu sözcüğün Anadolu sahasında sonradan ortaya çıkan bir sözcük olduğu görüşlerini destekler niteliktedir. Konargöçer terimi için bunu söyleyemeyiz. Her ne kadar günümüzde çağdaş Türk lehçelerinde konargöçer sözcüğ̈̈ yer almasa da sözcük, Eski Türkçe dönemi metinlerinde yer almaktadır. Burada dikkat çeken husus ise günümüzde Türkiye Türkçesinde muhacirler için kullanılan göçmen sözcüğünün anlam değişikliği yaşamayarak birçok çağdaş Türk lehçesinde Türk tipi göç faaliyetleri için kullanımının devam etmesidir.

Sonuç olarak adlandırmada çok başarılı olan bir dilin Bedevi Araplar, Çingeneler gibi milletlerin düzensiz göç faaliyetlerini karşılarken farklı bir sözcük türetmiş olabilme ihtimali göz ardı edilmemelidir. Kabul edilmeli ki Osmanlı belgelerinde ve Cumhuriyet döneminde "göçebe, konargöçer, göçerkonar, göçer, göçgün, göçmen” vb. göç merkezli sözcükler birbiri yerine o kadar çok kullanılmış 
ki bu durum kafaları karıştırmıştır. Cumhuriyet döneminde de bu hatalara devam edildiği için günümüzde terminoloji meselesi sürekli tartışılmaktadır. Osmanlı belgelerinde ilgili terimler yazılırken ileride bir karışıklık olabileceği düşünülmemiş olmalıdır lakin Cumhuriyet döneminde bu hataların devam ettirilmesi sonucu ilk Türkler için ve Yörük/Türkmen gruplar için uzun süre göçebe, tam göçebe, yarı göçebe, yatay göçebe, dikey göçebe, pastoral göçebe gibi ifadeler konargöçer, göçerkonar, göçer evli, göçgün, göçkün, göçmel, göçer, göçer oba vb. sözcüklerle birlikte ve bazen de o sözcüklerin yerine kullanılmıştır. Bu durumun bir örneği olarak bir makalede yer alan; "Dilimizde göçebelik, göçerlik, konar-göçerlik ve göçer-konaklık kavramları eş anlamlı olarak kullanılmakta olup herhangi bir çalışmada bu terimler fark gözetilmeden birbirinin yerine kullanılabilmektedir." (Ürker ve Çobanoğlu, 2014: 153) değerlendirmesi araştırmacıların konuya bakışını göstermektedir. Burada Ürker ve Çobanoğlu (2014) kendilerince haklı olabilirler çünkü bu terimleri birbiri yerine kullanan çok sayıda araştırmacı var. Lakin göz ardı ettikleri yer ise bu terimlerin ayrı anlamlara gelen terimler olduğunu savunan araştırmacı sayısının da çok olduğu gerçeğidir. Öncelikle konu üzerine çalışmalar yapan araştırmacıların terminoloji meselesi üzerine düşünerek çalışmalarında terim seçmeleri bu karışıklığı azaltabilir.

Çalışmamız verilerine dayanarak göçebe sözcüğünün düzensiz göç faaliyetleri içinde olan Çingeneler ve Bedevi Arapların göç faaliyetlerini karşılamak üzere kullanılması, konargöçer, göçerkonar, göçer, göçer evli, göçkün, göçgün sözcüklerinin Türk tipi göç faaliyetleri ve özellikle Yörük/Türkmen gruplar için kullanılması, göçmen sözcüğünün kendi ülkesini terk edip başka bir ülkeye yerleşen muhacir (kimse, aile veya halk) için kullanılması, göçmel sözcüğünün ise yaşadığı yeri geçici olarak bırakıp sonra tekrar dönen kuş vb. hayvanlar için kullanılmasının doğru olacağı sonucuna varılmıştır. Göçer evli, göçgün ve göçkün sözcükleri her ne kadar geçmişte Türk tipi göç faaliyetleri için kullanılmış olsalar da günümüzde çok fazla tercih edilen sözcükler değillerdir. Göçgüncü, göçküncü ve göçer oba sözcükleri ise artık kullanımdan düşmüştür.

\section{Çevri Yazı İşaretleri}

$[\bar{a}]$ : Normalden uzun a sesi

$[\overline{0}]$ : Normalden uzun o sesi.

$[\bullet]$ : Normalden uzun ö sesi.

[g்] : Art ünlülerle hece kuran katı, patlayıcı, ötümlü art damak ünsüzü.

[ñ] : Art ve ön ünlülerle hece kuran akıc1, patlayıcı, ötümlü, genizsi /n/ ünsüzü.

[>] : Gelişimin yönünü gösterir.

$[<]$ : Gelişimin yönünü gösterir. 


\section{KAYNAKÇA}

Ak, M. (2021). Batıll gezginlerin Yörük/Türkmen imgesi. Palet Yayınları.

Aka, İ. (2003). Anadolu'dan İran’a göçler. Tarihten Günümüze Türk-İran İlişkileri Sempozyumu (16-17 Arallk 2002) İçinde (s. 57-63). Türk Tarih Kurumu Yayınlar1.

Akgündüz, A. (1990). Osmanl Kanunnâmeleri ve hukuki tahliller. Fey Vakfi Yayınlar1.

Alyılmaz, C. (2013). Karı Çor Tigin yazıtı. TEKE-Uluslararası Türkçe Edebiyat Kültür Eğitim Dergisi, 2(2), 1-61.

Armağan, A. L. (1999). Osmanlı Devleti'nde Konar Göçerler. (Ed. Güler Erten). Osmanlı Ansiklopedisi İçinde (s. 142-150). Yeni Türkiye Yayınları.

Âşık Paşazade (2003). Osmanoğulları'nın tarihi-tevârih-i Âl-i Osman, (Hz. Kemal Yavuz \& M. A. Yekta Saraç). MAS Matbaacılık.

Âşık Paşazâde Tarihi (2013). (Hz. Necdet Öztürk). Bilge Kültür Sanat.

Ata, A. (1997). Kisasü'l-enbiya. Türk Dil Kurumu Yayınları.

Atmaca, E. (2016). Eski Oğuz Türkçesinden günümüz Türkiye Türkçesine söz varlığl ve anlam olayları. Palet Yayınları.

Ayverdi, İ. (2011). Kubbealtı lügatı misalli büyük Türkçe sözlük. Milliyet Kubbealtı Yayınları.

Bakır, A. (2008). Yazıcızâde 'Alî’nin Selçuk-nâme isimli eserinin edisyon kritiği, [Yayımlanmamış Doktora Tezi], Marmara Üniversitesi.

Barkan, Ö. L. (1943). XV. ve XVI. asırlarda Osmanl İmparatorluğunda zirâ̂ ekonominin hukukî ve malî esasları I, kanunlar. İstanbul Üniversitesi Edebiyat Fakültesi Yayınları.

Bayat, F. ve Aliyeva, M. E. (2008). Eski Türkçe sözlük. Yalın Yayıncılık.

Baykal, B. S. (1981). Tarih terimleri sözlüğü. Türk Dil Kurumu Yayılar1.

Baykara, T. (1987). Tarihte Türk devletleri. Ankara Üniversitesi Yayınları.

Baykara, T. (2001). Türk kültür tarihine baklşlar. Atatürk Araştırma Merkezi Yayınları. 
Beşirli, M. (2003). XIX. yüzyılın başlarına doğru Tokat Voyvodalı̆̆ı'na bağlı bazı Türkmen kabilelerin sorunları. Cumhuriyet Üniversitesi Sosyal Bilimler Enstitüsü Dergisi, XXVII(2), 289-307.

Bilgili, A. S. (2000). Tarsus Türkmenleri (Varsaklar). (Hz. Tufan Gündüz). Anadolu'da ve Rumeli'de Yörükler ve Türkmenler Sempozyumu Bildirileri İçinde (s. 9-49). Yörük Türkmen Vakfi.

Bostan, M. H. (2000). XV. ve XVI. yüzylllarda Karadeniz sahil sancaklarında Türkmenler. (Hz. Tufan Gündüz). Anadolu'da ve Rumeli'de Yörükler ve Türkmenler Sempozyumu Bildirileri İçinde (s. 51-69). Yörük Türkmen Vakfi.

Bozkurt, F. ve Özgüzel, S. (2019). Türklerde yaşam tarzı olarak göç olgusu 'göç yolda düzelir'. Folklor/edebiyat, 25(100), 815-824.

Bulduk, Ü. (2008). Sosyal yaşayış, konar-göçerlik ve etnisite. Uyan Türkiyem II. Yörük-Türkmen Büyük Kurultayı ve Bilim Şenliği (3-4 Mayıs 2008, Ankara) İçinde (s. 216-223). Türkboy Yayınları.

Büyükcan Sayılır, Ş. (2012). Göçebelik, konar-göçerlik meselesi ve coğrafi bakımdan konar-göçerlerin farklılaşması. Türk Dünyası İncelemeleri Dergisi. 12(1), 563-580.

Clauson, S. G. (1972). An etymological dictionary of pre-thirteenth-century Turkish. Oxford University Press.

Çelik, Ș. (2000). XVI. yüzyılda İçel Yörükleri hakkında bazı değerlendirmeler. (Hz. Tufan Gündüz). Anadolu'da ve Rumeli'de Yörükler ve Türkmenler Sempozyumu Bildirileri İçinde (s. 83-101). Yörük Türkmen Vakfı.

Denker, B. (1960). Güneydoğu Toroslarda göçebelik (Dr. Wolf-Dieter Hütteroth’a göre). Türk Coğrafya Dergisi, 16(20), 136-142.

Doerfer, G. (1967). Türkische und Mongolische elemente im neupersischen. Wiesbaden.

Duran, H. (2007). Velâyetnâme. Diyanet Vakfı Yayınları.

Durgut, H. (1995). "Şeyh Süleymân Efendî-i Buhâri Lügat-i Çağatay ve Türkî-i Osmânî (Cild-i Evvel)” adlı eserin transkripsiyonu, [Yayımlanmamış Yüksek Lisans Tezi], Trakya Üniversitesi.

Dülger, E. (2012). Oruç Bey’in Tevârih-i Âl-i Osmân adlı eserine göre Türklerde yer adı verme geleneği. Turkish Studies, 7(4), 1067-1074.

Eraslan, K. (2012). Eski Uygur Türkçesi grameri. Türk Dil Kurumu Yayınları. 
Ercilasun, A. B. ve diğerleri (1992). Karşılaş̧trmalı Türk Lehçeleri sözlüğü. Kültür Bakanlığı Yayınları.

Ergin, M. (2006). Orhun abideleri, (37. Baskı). Boğaziçi Yayınları.

Ergin, M. (2009). Dede Korkut kitabı-1. Türk Dil Kurumu Yayınları.

Erinç, S. (1973). Türkiye: insan ve ortam. İstanbul Üniversitesi Coğrafya Enstitüsü Dergisi, X(18-19), 1-33.

Eröz, M. (1991). Yörükler. Türk Dünyası Araştırmalar Vakfı Yayınları.

Eyüboğlu, İ. Z. (1988). Türkçe kökler sözlüğü. Remzi Kitabevi.

Gabain, A. Von. (2003). Eski Türkçenin grameri, (Çeviren: Mehmet Akalın). Türk Dil Kurumu Yayınları.

Gökbilgin, M. T. (1957). Rumeli'de Yörükler, Tatarlar ve Evlâd-ı Fâtihan. İstanbul Üniversitesi Edebiyat Fakültesi Yayınları.

Gökyay, O. Ş. (1981). Türkçede “-mal” ve “-mel” eki üzerine. Türk Dili Araştırmaları Yıllığı-Belleten 1978-1979. 0(0), 23-32.

Gömeç, S. (1995). Terhin Yazıtı'nın tarihi açıdan değerlendirilmesi. Tarih Araștırmaları Dergisi. 17(28), 71-84.

Gülensoy, T. (2011). Türkiye Türkçesindeki Türkçe sözcüklerin köken bilgisi sözlüğü I, (2. Baskı). Türk Dil Kurumu Yayınları.

Güler, A. (2015). Atatürk'ün soyu: Kızıl Oğuzlar (Kocacıklar) ve Konyarlar. Türk Tarih Araştırmaları, 0(0), 1-35.

Gülsoy, E. (2000). XVI. yüzyılda Trablus-Şam ve Hama ve Humus Türkmenleri. (Hz. Tufan Gündüz). Anadolu'da ve Rumeli'de Yörükler ve Türkmenler Sempozyumu Bildirileri İçinde (s. 121-124). Yörük Türkmen Vakfi.

Gündüz, T. (2002). Konar göçer. İslam Ansiklopedisi, (C. 26) İçinde (s. 161-162). Türkiye Diyanet Vakfı Yayınları.

Gürbüz, O. (1997). Türkiye'de göçebe mesken örneği: çadır. Türk Coğrafya Dergisi, 0(32), 185-195.

Gürsoy Naskali, E. ve Duranl1, M. (1999). Altayca-Türkçe sözlük. Türk Dil Kurumu Yayınları.

Güvenç, B. (1971). Kültür sinıflaması denemeleri. Hacettepe Sosyal ve Beşerî İlimler Dergisi, II(1), 9-19. 
Güzel, F. (2018). Türkiye Türkçesi ağızlarında yapım ekleri I: yazı dilinde bulunmayan yapım ekleri. Türk Dili Araştırmaları Yıllığı-Belleten, 66(1), 73-114.

Hadidi (1523). Tarih-i Âl-i Osman, (Tarayan: Kilisli Muaallim Rifat Bilge). Bayezit Kitaplı̆ğ.

Halaçoğlu, Y. (1988). XVIII. yüzyılda Osmanlı Imparatorluğu'nun iskân siyaseti ve aşiretlerin yerleştirilmesi. Türk Tarih Kurumu Yayınları.

Halaçoğlu, Y. (2009). Anadolu'da aşiretler, cemaatler ve oymaklar 1453-1650. Türk Tarih Kurumu Yayınları.

İğci, A. (2011). Anonim Tevârih-i Âl-i Osman (687-920/1228-1514) -inceleme ve metin-, [Yayımlanmamış Yüksek Lisans Tezi], Marmara Üniversitesi.

İnbaş1, M. (2000). Rumeli Yörükleri. (Hz. Tufan Gündüz). Anadolu'da ve Rumeli'de Yörükler ve Türkmenler Sempozyumu Bildirileri İçinde (s. 145182). Yörük Türkmen Vakfi.

Kafesoğlu, İ. (2005). Türk milli kültürü. Ötüken Yayınları.

Karataş, M. (2017). Göçerevlilik ve yerleşiklik bağlamında Selçuknâme'deki kültür unsurlar1. TÜBAR, 22(42), 127-170.

Kaşgarlı Mahmud (2018). Dîvânu Lügâti't-Türk. (Hz. Ahmet Bican Ercilasun \& Ziyat Akkoyunlu). Türk Dil Kurumu Yayınları.

Khazanov, A. (1986). Nomads and the outside world. Cambridge University Press, New York.

Koçak, Y. ve Terzi, E. (2012). Türkiye'de göç olgusu, göç edenlerin kentlere olan etkileri ve çözüm önerileri. Kafkas Üniversitesi İktisadi ve İdari Bilimler Fakültesi Dergisi, 3(3), 163-184.

Korkmaz, Z. (2007). Türkiye Türkçesi grameri şekil bilgisi. Türk Dil Kurumu Yayınları.

Köse, A. (2005). Türkiye'de geleneksel kırsal konut planlarında göçebe Türk kültürü izleri. Afyon Kocatepe Üniversitesi Sosyal Bilimler Enstitüsü, VII(2), 165-200.

Kutlu, M. M. (1987). Şavaklı Türkmenlerde göçer hayvancıllk. Kültür ve Turizm Bakanlığı Yayınları. 
Kutlu, M. M. (2000). Göçerlerde mekânsal düzenleme: çadır-ev ilişkisi. (Hz. Tufan Gündüz). Anadolu'da ve Rumeli'de Yörükler ve Türkmenler Sempozyumu Bildirileri İçinde (s. 211-216). Yörük Türkmen Vakfi.

Küçük, S. ve Ateş, M. (2017). Ordu ăgzı söz varlığı. Gece Kitaplığı Yayınları.

Malçok Meteer, M. (2012). Vilâyetnâme-i Hacı Bektâş-1 Veli (İnceleme-MetinDizin) (103a-204a), [Yayımlanmamış Yüksek Lisans Tezi], Trakya Üniversitesi.

Mütercim Âsım Efendi (2009). Burhân-ı katı. (Hz. Mürsel Öztürk \& Derya Örs). Türk Dil Kurumu Yayınları.

Mütercim Âsım Efendi (2013). Kâmûsu'l-muhît tercümesi. (Hz. Mustafa Koç \& Eyyüp Tanrıverdi). Türkiye Yazma Eserler.

Nişanyan, S. (2021). Çağdaş Türkçenin etimolojisi. https://www.nisanyansozluk.com/?k=g\%C3\%B6\%C3\%A7ebe adresinden 7.10.2021 tarihinde erişildi.

Nişanyan, S. (2021). Çağdaş Türkçenin etimolojisi. https://www.nisanyansozluk.com/?k=g\%C3\%B6\%C3\%A7men\&lnk=1 adresinden 10.10.2021 tarihinde erişildi.

Nişanyan, S. (2021). Çağdaş Türkçenin etimolojisi. https://www.nisanyansozluk.com/?k=g\%C3\%B6\%C3\%A7men adresinden 30.09.2021 tarihinde erişildi.

Orhonlu, C. (1963). Osmanlı İmparatorluğu'nda Aşiretleri iskan teşebbüsü 16911699. İstanbul Edebiyat Fakültesi Yayınları.

Ögel, B. (1978). Türk kültür tarihine giriş 1. Kültür ve Turizm Bakanlığı Yayınları.

Ögel, B. (1995). Türk mitolojisi, (II. Cilt). Türk Tarih Kurumu Yayınları.

Ögel, B. (2000). Türk kültür tarihine giriş, (C.1). Kültür Bakanlığı Yayınları.

Öngör, S. (1964). Ortadoğu ülkelerinde göçebe hayatının bugünkü şartları ve göçebe nüfusunun sedantarizasyonu. A.Ü. Siyasal Bilgiler Fakültesi Dergisi, 9(1), 145-160.

Öztelli, C. (1959). Karacaoğlan hayatı sanatı şiirleri. Varlık Yayınevi.

Pakalın, M. Z. (1971). Osmanl tarih deyimleri ve terimleri sözlüğü, (C. II). Milli Eğitim Bakanlı̆̆ı Yayınları. 
Radloff, W. (1899). Versuch eines Wörterbuches der Türk-Dialekte II. S. Petersburg.

Räsänen, M. (1957). Materialien zur morphologie der Türkischen sprachen. StO, XXI, Helsinki.

Sahillioğlu, H. (2002). Topkapı Sarayı arşivi H. $951-952$ tarihli ve e-12321 numaralı mühimme defteri. IRCICA Yayınları.

Saydam, A. (2009). Sultanın özel statüye sahip tebaası: konar-göçerler. SDÜ Fen Edebiyat Fakültesi Sosyal Bilimler Dergisi, 0(20), 145-160.

Sevortyan, E. V. (1974). Etimologiçeskiy slovar Tyurkskih yazıkov I (1974), II (1978), III (1980), IV (1989), V (1997), VI (2000). Moskova.

Spooner, B. (1972). The Status of nomadism as a cultural phenomenon in the Middle East. Perspectives on Nomadism, Leiden.

Sümer, F. (1960). Anadolu’ya yalnız göçebe Türkler mi geldi? Belleten, XXIV(96), 567-594.

Şahin, C. (2001). Yurt dışı göçün bireyin psikolojik sağlığı üzerindeki etkisine ilişkin kuramsal bir inceleme. Gazi Üniversitesi Ĕ̆itim Fakültesi Dergisi, 21(2), 57-67.

Şahin, İ. (2006). Osmanlı döneminde konar-göçerler. Eren Yayıncılık.

Şahin, İ. (2020). Göç kavramı üzerine. (Ed. Fatih Uslu \& Canan Köküş). Yörük Araştırmaları 2 İçinde (s. 15-24). Palet Yayınları.

Şenel, A. (1968). Eski Yunan'da siyasal düşünce. İstanbul Üniversitesi Siyasal Bilgiler Fakültesi Yayınları.

Şimşir, S. (2019). Şah İsmail: hayatı ve şahsiyeti. Akademik Tarih ve Düşünce Dergisi, 6(5), 74-86.

Tavkul, U. (2000). Karaçay-Malkar Türkçesi sözlüğü. Türk Dil Kurumu Yayınları.

Telli, B. ve Bulduk, T. B. (2018). Adıyaman ili ve yöresi ă̆ızları söz varlı̆̆ı. Gazi Kitabevi Yayınları.

Toparlı, R.; Vural, H. ve Karaatlı, R. (2014). Kıpçak Türkçesi sözlüğü. Türk Dil Kurumu Yayınları.

Türk Dil Kurumu (2009). Derleme sözlüğ̈̈, (II. Cilt). Türk Dil Kurumu Yayınları.

Türk Dil Kurumu (2009). Derleme sözlüğü, (III. Cilt). Türk Dil Kurumu Yayınları. 
Türk Dil Kurumu (2009). Tarama Sözlüğ̈̈, (III. Cilt). Türk Dil Kurumu Yayınları.

Türk Dil Kurumu (2009). Tarana Sözlüğ̈̈, (IV. Cilt). Türk Dil Kurumu Yayınları.

Türk Dil Kurumu (2011). Türkçe sözlük. Türk Dil Kurumu Yayınları.

Türkay, C. (1979). Başbakanlık arşiv belgelerine göre Osmanlı Imparatorluğunda oymak, aşiret ve cemaatler. Tercüman Gazetesi Yayınları.

Uslu, F. (2019). Yörük obalarındaki yaşayıştan günümüze uzanan yaşam şekilleri ve modernite etkisinde bir kent okuması. (Editör: Fatih Uslu). 1. Uluslararası Antalya Yörük Sempozyumu Tam Metin Kitabı (6-8 Aralı 2019) İçinde (s. 117-127). Sage Yayınları.

Ünlü, S. (2013). Çağatay Türkçesi sözlüğü. Eğitim Yayınevi.

Ürker, O. ve Çobanoğlu, N. (2014). Türkiye'de doğal varlıkların sürdürülebilir kullanımında biyoetiğin bir araç olarak kullanılması; Batı Anadolu Yörükleri üzerinden örnek olay incelemesi. Ankara Üniversitesi Sosyal Bilimler Dergisi, 5(1), 151-171.

Yediyıldız, B. (2018). Ordu tarihinden izler. Kültür Yayınları.

Yılmaz, A. ve Telci, C. (2010). Türk kültür terminolojisinde göç kavramı üzerine. Modern Türklük Araştırmaları Dergisi, 7(2), 14-33. 